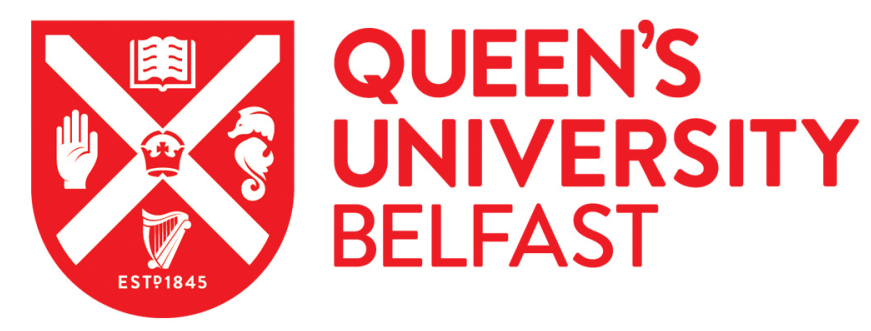

\title{
Accuracy of maturity functions' strength estimates for fly ash concretes cured at elevated temperatures
}

Soutsos, M., Kanavaris, F., \& Elsageer, M. (2020). Accuracy of maturity functions' strength estimates for fly ash concretes cured at elevated temperatures. Construction and Building Materials, 266(121043), [Volume 266, Part B, 10 January 2021, 121043]. https://doi.org/10.1016/j.conbuildmat.2020.121043

Published in:

Construction and Building Materials

Document Version:

Peer reviewed version

Queen's University Belfast - Research Portal:

Link to publication record in Queen's University Belfast Research Portal

Publisher rights

Copyright 2020 Elsevier.

This manuscript is distributed under a Creative Commons Attribution-NonCommercial-NoDerivs License

(https://creativecommons.org/licenses/by-nc-nd/4.0/), which permits distribution and reproduction for non-commercial purposes, provided the author and source are cited.

\section{General rights}

Copyright for the publications made accessible via the Queen's University Belfast Research Portal is retained by the author(s) and / or other copyright owners and it is a condition of accessing these publications that users recognise and abide by the legal requirements associated with these rights.

Take down policy

The Research Portal is Queen's institutional repository that provides access to Queen's research output. Every effort has been made to ensure that content in the Research Portal does not infringe any person's rights, or applicable UK laws. If you discover content in the Research Portal that you believe breaches copyright or violates any law, please contact openaccess@qub.ac.uk. 
1 Accuracy of maturity functions' strength estimates for fly ash

2 concretes cured at elevated temperatures

3 Marios Soutsos $^{1, \mathrm{a}^{*}}$, Fragkoulis Kanavaris ${ }^{2, \mathrm{~b}}$ and Mohammed Elsageer ${ }^{3, \mathrm{a}}$

4

$5 \quad{ }^{1}$ School of Natural and Built Environment, Queen's University Belfast, Northern

6 Ireland, UK.

$7 \quad{ }^{2}$ Specialist Technology and Research, ADE, ARUP Group, London UK.

$8 \quad{ }^{3}$ Civil Engineering Department, Sirte University, Libya.

9

10 a $\underline{\text { m.soutsos@qub.ac.uk }}(*$ corresponding author $)$

11 b $\underline{\text { frag.kanavaris@ arup.com }}$

12 ㄷdrmohammedalsger@gmail.com

13

14 


\section{Highlights}

16 - Fly ash concretes are less sensitive to high temperatures than Portland cement.

17 - Fly ash concretes have lower "apparent" activation energies than Portland 18 cement.

19 - The Nurse-Saul function underestimated early age strengths at elevated curing temperatures.

- The Arrhenius function overestimated the early age strengths of Portland

25

\section{Notation}

$\begin{array}{lll}27 & E_{a} & \text { "apparent" activation energy }(\mathrm{J} / \mathrm{mol}) \\ 28 & k & \text { the rate constant }(1 / \text { day }) \\ 29 & M & \text { Nurse-Saul maturity }\left({ }^{\circ} \mathrm{C} \cdot \text { days }\right) \\ 30 & R & \text { universal gas constant }\left(\mathrm{J} /{ }^{\circ} \mathrm{K} \cdot \mathrm{mol}\right) \\ 31 & S & \text { compressive strength }(\mathrm{MPa}) \\ 32 & S_{\infty} & \text { ultimate compressive strength }(\mathrm{MPa}) \\ 33 & T & \text { average temperature }\left({ }^{\circ} \mathrm{C}\right) \\ 34 & T_{0} & \text { datum temperature }\left({ }^{\circ} \mathrm{C}\right) \\ 35 & T_{a b s} & \text { absolute temperature }\left({ }^{\circ} \mathrm{K}\right) \\ 36 & T_{r} & \text { specified reference temperature }\left({ }^{\circ} \mathrm{K} \text { or }{ }^{\circ} \mathrm{C}\right) \\ 37 & t_{0} & \text { age at which mortar strength development is assumed to begin (days) } \\ 38 & t_{e} & \text { equivalent age (days) } \\ 39 & \alpha & \text { age conversion factor } \\ 40 & \Delta t & \text { time interval (days) } \\ 41 & & \end{array}$




\section{Abstract}

43 The effect of elevated curing temperature on the strength development of concrete mixes 44 with fly ash (FA) has been investigated for strength grades C32/40 and C55/67. 45 Percentages of fly ash in the total binder were 15, 30 and 45 per cent. High curing 46 temperatures have a beneficial effect on the early age strength but a detrimental effect on the long-term strength development. Fly ash (FA) concrete mixes have been shown to be less sensitive to curing at high temperatures than Portland cement (PC) concretes and this was reflected in their lower "apparent" activation energies. The accuracy of strength estimates obtained from maturity functions was examined. The temperature dependence of the Nurse-Saul function, i.e. the concrete strength gain rate varies linearly with temperature, was not sufficient to account for the improvement in early age strengths resulting from high curing temperatures. The Arrhenius based function, on the other hand, overestimated them because of the detrimental effect of high curing temperature on strength starting from a very early age. Both functions overestimate long term strengths as neither accounts for the detrimental effect of high curing temperatures on the ultimate compressive strength.

\section{Keywords}

"Apparent" activation energy, maturity functions, strength development, strength estimates, fly ash

63 


\section{$71 \quad 1 \quad$ Introduction}

72

73

74

75

76

77

78

79

80

81

82

84

85

86

87

88

89

90

91

92

93
The need to understand and quantify the effect of temperature on the early age strength development of concrete mixes has been recognised for a long time. The need was mainly for: a) determining elevated curing temperatures needed to achieve the required early age strengths (Saul, 1951) for safely lifting precast concrete elements as early as sixteen hours after casting and, b) predicting the in-situ strength, especially during cold weather concreting, to allow safe stripping of formwork and removal of props avoiding collapses like the Willow Island one (1978) which resulted in 51 deaths (Lew et al. 1979; Feld and Carper, 1997). This can be achieved with maturity methods which account for the combined effect of time and temperature on the strength development of concrete (Barnett et al. 2007a; Brooks et al. 2007; Galobardes et al. 2015, Sofi et al. 2012, Yikici et al. 2015; Soutsos et al. 2016, 2018a, 2019; Vollpracht, 2018).

Saul (Saul, 1951) proposed a single factor, i.e. "maturity", to be indicative of the concrete strength irrespective of the combination of temperature and time that make up that maturity:

$$
M=\sum_{t}\left(T-T_{0}\right) \cdot \Delta t
$$

\section{Equation 1}

where: $\quad \mathrm{M} \quad$ is the maturity $\left({ }^{\circ} \mathrm{C} \cdot\right.$ days $)$,

$\mathrm{T}$ is the average temperature $\left(20^{\circ} \mathrm{C}\right.$ for standard curing) over the time interval $\Delta \mathrm{t}\left({ }^{\circ} \mathrm{C}\right)$,

$\mathrm{T}_{0} \quad$ is the datum temperature $\left({ }^{\circ} \mathrm{C}\right)$, $\Delta \mathrm{t} \quad$ is the time interval (days). 

expressed in a form of an equivalent age, in which a given temperature-time curing history corresponds to an equivalent age of curing at a reference temperature, as given by Equation 2 .

100

101

$$
t_{e}=\frac{\sum\left(T-T_{0}\right)}{\left(T_{r}-T_{0}\right)} \cdot \Delta t
$$

103 where: $t_{\mathrm{e}}$ is the equivalent age at the reference temperature (days),

$$
\mathrm{T}_{\mathrm{r}} \quad \text { is the reference temperature }\left({ }^{\circ} \mathrm{C}\right) \text {. }
$$

105

107 (1954), has become particularly convenient when it comes to using other formulations

108 besides Equation 1 to account for the combined effects of temperature and time on the

109 strength development of concrete.

110 The assumption that the strength development rate follows the Arrhenius

111 principle leads to the maturity function (Equation 3), referred to as Arrhenius function in 112 this paper (Freiesleben and Pedersen, 1977).

$$
t_{e}=\sum e^{-\frac{E a}{R} \cdot\left(\frac{1}{T_{a}}-\frac{1}{T_{s}}\right)} \cdot \Delta t
$$


116 where: $t_{e}$ is the equivalent age (days),

$117 \mathrm{~T}_{\mathrm{a}}$ is the average temperature of concrete during time interval $\Delta \mathrm{t}(\mathrm{K})$,

$118 \mathrm{~T}_{\mathrm{s}}$ is the specified reference temperature $(\mathrm{K})$,

$119 \mathrm{E}_{\mathrm{a}}$ is the "apparent" activation energy $(\mathrm{J} / \mathrm{mol})$,

$120 \mathrm{R}$ is the universal gas constant $(\mathrm{J} / \mathrm{K} \cdot \mathrm{mol})$.

121

122

123

124

125

126

128

129

130

131

132

$$
S=\frac{S_{u} \cdot k \cdot\left(t-t_{0}\right)}{1+k \cdot\left(t-t_{0}\right)}
$$

134 where: $\mathrm{S}$ is the compressive strength at age $\mathrm{t}(\mathrm{MPa})$, recommended) was considered to increase the accuracy of the results.

The "apparent" activation energies can be determined with "equivalent" mortar specimens, as described in ASTM Standard C1074-98 (ASTM, 2011). However, concrete specimens were used despite these requiring much bigger volumes of materials. Strength development for five curing temperatures (instead of only three as is

Regression analysis is needed in order to relate concrete strength to age or maturity index (Carino, 2004; Freiesleben and Pedersen, 1985; Carino and Tank, 1992). The S-shape function proposed by Carino (Carino and Tank, 1992; Tank and Carino, 1991) (Equation 4) is the one recommended in ASTM C1074-11 (ASTM, 2011). 
138

139

140

141

142

143

144

145

146 $\mathrm{t}_{0} \quad$ is the age at which compressive strength development is assumed to begin (days).

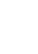

The rate constant, $k$, the ultimate strength, $S_{u}$, and the age at which strength development begins, to, of each mortar mixture is determined at all investigated curing temperatures through regression analysis.

ASTM C1074-11 (ASTM, 2011) recommendation for the calculation of the "apparent" activation energy, $E_{a}$, is to plot $\ln (k)$ against $1 / T_{a b s}$ (given in $1 /$ Kelvin), where $T_{a b s}$ is the absolute curing temperature. The slope of the trend line is equal to $-Q$ and the "apparent" activation energy $\left(E_{a}\right)$ for the mixture will be equal to $Q \cdot R$, where $R$ is the universal gas constant equal to $8.31 \mathrm{~J} / \mathrm{K} \cdot \mathrm{mol}$.

It is recognised that these maturity functions were developed for Portland cement concrete. There is a need nowadays to determine the applicability/accuracy of maturity functions for other than CEM I concretes. The temperature sensitivity of fly ash (FA) has been shown to be different from that of Portland cement (Soutsos et al., 2013, 2017; Boubekeur et al., 2014). It is therefore necessary to examine the applicability/accuracy of these maturity functions for concretes with FA especially now that new types of cements (CEM II - Portland composite cement, CEM IV - pozzolanic cement and CEM $\mathrm{V}$ - composite cement) are gaining popularity because of their lower than CEM I Portland cement carbon footprint. CEM IIB-V and CEM IVB-V which contain 21-35\% and $36-55 \%$ FA, respectively, is also highly recommended for exposure classes XS1, XS2, and XS3 (corrosion induced by chlorides from sea water) and XD1, XD2, XD3 (corrosion induced by chlorides other than sea water) (BSI, 2016) and if specified then it 
161 is expected to cause problems for precast concrete factories. The required early age

162 strength, e.g., $15 \mathrm{MPa}$ for reinforced and $24 \mathrm{MPa}$ for prestressed concretes at 16 hours,

163 may only be achieved with high early age curing temperatures and these need to be

164 applied as soon as concrete is cast and without the "delay period" before the "temperature

165 rise period" as is normally recommended for precasting works (Neville and Brooks,

166 2010). Maturity functions can help to determine the elevated curing temperature needed

167 to achieve the required early age strengths for safely lifting precast concrete elements.

168 Considerable number of publications dealing with the use of GGBS in concrete and

169 "apparent" activation energies of concretes with GGBS have been published. There are

170 however only few publications that have determined "apparent" activation energies for

171 fly ash (FA) concretes.

172 The aim of this investigation was therefore to quantify the effect of high early age

173 curing temperatures (a) on the compressive strengths of fly ash concretes, (b) determine

174 "apparent" activation energies that can be used in maturity functions for estimating the

175 curing temperature needed to achieve the required early age strengths, and (c) determine

176 the accuracy of maturity functions in estimating the strength at elevated curing 177 temperatures.

178

1792 Materials and experimental procedures

180 The mix proportions of concretes investigated, and which had nominal cube

181 compressive strengths of 50 and $75 \mathrm{MPa}$ at 28-days, are shown in Table 1 . These

182 concretes correspond to Grade C32/40 and C55/67 if approximately $10 \mathrm{MPa}$ is allowed

183 as the margin between the characteristic and the 28-day nominal cube compressive 
184 strength. The other variable investigated, i.e. other than the concrete grade, was the

185 percentage of fly ash in terms of the total binder, i.e. 15,30 and 45 per cent. Lower

186 water-binder ratios were required to maintain the compressive strength with increasing fly ash.

187 Total binder contents for the concrete grade C32/40 series increased to maintain as much as

188 possible a slump value between 50 to $150 \mathrm{~mm}$. Total binder contents are shown in Table 2 .

189 Mixes for the concrete grade C55/67 series were designed according to the Modified Maximum

190 Density Theory which assumes that the paste volume required for a mix is what is required to

191 fill the voids in the aggregate plus an additional 5\% of the total concrete volume to separate the

192 aggregate sufficiently, and thus act as a lubricant to achieve a workable concrete (Domone and

193 Soutsos, 1994). It is not therefore the paste volume that dictates the consistency or the

194 workability of the concrete but the fluidity of the paste. A superplasticizer is therefore needed,

195 and the dosage increases with lower water-binder ratios as shown in Table 2.

196

197 Table 2: $\quad$ Mix proportions of concrete mixes investigated

198

\begin{tabular}{|c|c|c|c|c|c|c|c|c|}
\hline \multirow{2}{*}{ Material } & \multicolumn{4}{|c|}{ Concrete Grade C32/40 } & \multicolumn{4}{|c|}{ Concrete Grade C55/67 } \\
\hline & PC40 & $15 F A 40$ & $30 F A 40$ & $45 F A 40$ & PC67 & $15 F A 67$ & $30 F A 67$ & $45 F A 67$ \\
\hline Cement $\left[\mathrm{kg} / \mathrm{m}^{3}\right]$ & 389 & 345 & 302 & 269 & 317 & 285 & 244 & 203 \\
\hline $\begin{array}{c}\text { Fly Ash (FA) } \\
{\left[\mathrm{kg} / \mathrm{m}^{3}\right]}\end{array}$ & - & 61 & 129 & 220 & - & 50 & 105 & 166 \\
\hline $\begin{array}{c}\text { Total binder } \\
\text { content }\left[\mathrm{kg} / \mathrm{m}^{3}\right]\end{array}$ & 389 & 406 & 431 & 489 & 317 & 335 & 349 & 369 \\
\hline Gravel $\left[\mathrm{kg} / \mathrm{m}^{3}\right]$ & 1189 & 1250 & 1249 & 1244 & 1426 & 1426 & 1426 & 1426 \\
\hline Sand $\left[\mathrm{kg} / \mathrm{m}^{3}\right]$ & 612 & 575 & 561 & 508 & 612 & 612 & 612 & 612 \\
\hline Free water $\left[\mathrm{kg} / \mathrm{m}^{3}\right]$ & 210 & 203 & 190 & 183 & 146 & 136 & 124 & 110 \\
\hline $\begin{array}{c}\text { Superplasticiser } \\
\text { [\% of binder] }\end{array}$ & - & - & - & - & 0.20 & 0.25 & 0.27 & 0.35 \\
\hline $\begin{array}{c}\text { Free water-binder } \\
(w / b) \text { ratio }\end{array}$ & 0.54 & 0.5 & 0.44 & 0.37 & 0.46 & 0.41 & 0.35 & 0.30 \\
\hline
\end{tabular}




\begin{tabular}{|c|c|c|c|c|c|c|c|c|}
\hline Slump [mm] & 100 & 120 & 95 & 40 & 115 & 60 & 105 & 170 \\
\hline k-factor & - & 0.49 & 0.38 & 0.31 & - & 0.13 & 0.24 & 0.23 \\
\hline $\begin{array}{c}\text { 32-day strength } \\
\text { [MPa]* }\end{array}$ & 54 & 50 & 51 & 54 & 73 & 82 & 77 & 74 \\
\hline
\end{tabular}

199

\section{Table 2:}

213

Strengths are at 32 instead of the normal 28 days as this was required for determination of the "apparent" activation energies.

\subsection{Materials}

Portland cement (PC) with 28-day compressive strength of $57 \mathrm{MPa}$ (determined based on BS EN 196-1:2005 (BSI, 2005)) and that conformed to BS EN 197-1:2011 (BSI, 2011) was supplied by Castle Cement Ltd and its chemical composition is shown in Table 2. PC was partially replaced with FA, conforming to BS EN 450-1:2012 (BSI, 2012), and which was supplied by Hargreaves Coal Combustion Products Ltd and its chemical composition is also shown in Table 2.

\section{Chemical composition of $P C$ and FA.}

\begin{tabular}{|c|c|c|}
\hline \multirow[t]{2}{*}{ Oxides } & \multicolumn{2}{|c|}{$\%$ composition } \\
\hline & Portland cement & Fly ash \\
\hline $\mathrm{CaO}$ & 63.4 & 3.0 \\
\hline $\mathrm{SiO}_{2}$ & 20.6 & 48.1 \\
\hline $\mathrm{Al}_{2} \mathrm{O}_{3}$ & 5.5 & 29.5 \\
\hline $\mathrm{Fe}_{2} \mathrm{O}_{3}$ & 2.4 & 8.0 \\
\hline $\mathrm{SO}_{3}$ & 2.8 & 0.8 \\
\hline MgO & 2.6 & 2.5 \\
\hline $\mathbf{K}_{2} \mathbf{O}$ & 0.7 & 2.5 \\
\hline $\mathrm{Na}_{2} \mathrm{O}$ & 0.2 & 1.2 \\
\hline LOI & 1.8 & 4.8 \\
\hline \multicolumn{3}{|c|}{ Clinker compounds (as measured) } \\
\hline $\mathrm{C}_{3} \mathrm{~S}$ & 58.4 & \multirow{3}{*}{ - } \\
\hline $\mathrm{C}_{2} \mathrm{~S}$ & 17.1 & \\
\hline $\mathrm{C}_{3} \mathrm{~A}$ & 9.9 & \\
\hline
\end{tabular}




\begin{tabular}{|l|l|l|}
\hline C4AF & 7.7 & \\
\hline
\end{tabular}

216 The coarse aggregate used in this study was a 5-20 $\mathrm{mm}$ well graded crushed granite with

217 a water absorption of $0.79 \%$ whilst the fine aggregate used was well graded medium sand 218 with a water absorption of $0.64 \%$. The particle size distributions for the coarse and fine 219 aggregate used are shown in Figure 1 alongside with the corresponding grading limits of 220 BS 882:1992 (BSI, 1992) which was used at the time the experimental work of the project 221 was carried out. This has since been replaced by BS EN 12620:2002+A1:2008 (BSI, 222 2002). The superplasticizer used was Structuro 11180, which is polycarboxylate ether 223 based, and it was supplied by FOSROC Ltd UK. A polycarboxylate ether-based 224 superplasticizer was chosen as this does not have a retardation effect on concrete strength 225 development and its effect on the "apparent" activation energies has been reported in the 226 literature to be very small or none at all (Wirquin et al. 2002; Poole et al. 2011). 


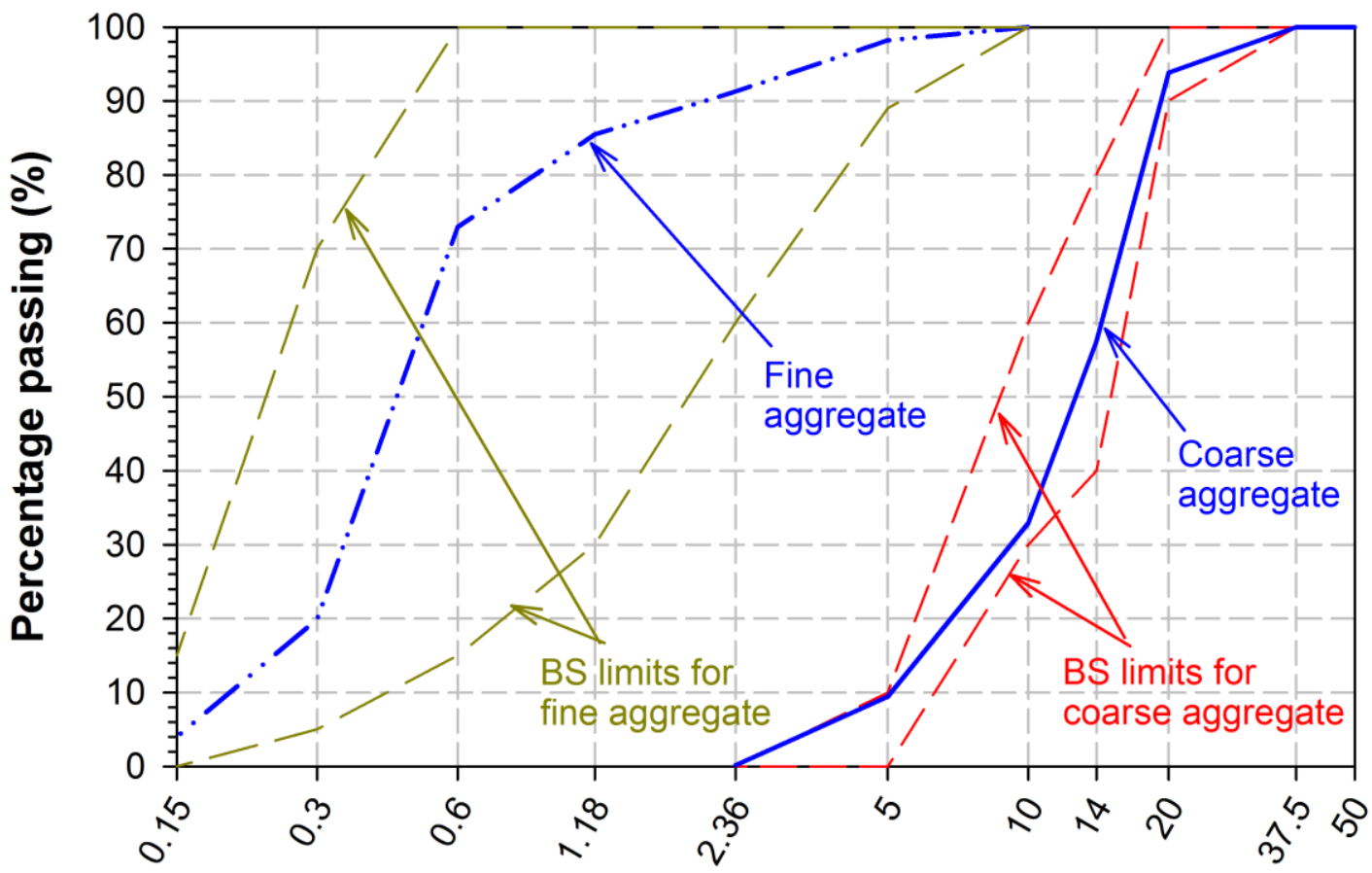

Nominal sieve size $(\mathrm{mm})$

Figure 1: Sieve analysis of coarse and fine aggregate used.

\subsection{Mixing, casting, curing and testing procedures}

237 A horizontal pan mixer with a capacity of $0.1 \mathrm{~m}^{3}$ was used for concrete mixing and the 238 materials were added in the mixer in the following order: aggregates, PC, fly ash and water containing the superplasticizer if used. The coarse and fine aggregate were ovendried and allowance for this was made in the added water. Aggregates were firstly added into the pan with half of the water and they were mixed for two minutes. The binders, water and superplasticizer were then added and mixing continued for approximately three minutes to ensure mix homogeneity. The concrete was then cast into $100 \mathrm{~mm}$ three-gang

244 cube moulds, compacted on a vibrating table in two phases and wrapped in polyethylene 245 film. The cubes were then transferred to water tanks for curing at 10, 20, 30, 40 and $24650{ }^{\circ} \mathrm{C}$. They were subsequently demoulded at the time of the first compressive strength test. Three cubes were tested at eight to ten testing ages for each mixture/temperature 
248 combination. Subsequent tests were carried out at twice the age of the previous test as

249 described in ASTM C1074 (ASTM, 2011).

\section{Results and discussion}

252

253 The first part of the work determined the strength versus water-binder ratio (w/b)

254 relationships for concretes with $15,30 \& 45 \%$ cement replacement with FA. The second 255 part was the investigation of the strength development at elevated curing temperatures. 256 These were subsequently used in the third part for determining the "apparent" activation 257 energies. The fourth part used the Nurse-Saul and Arrhenius functions for estimating the 258 strength development at elevated curing temperatures. The accuracy of these maturity 259 functions was determined by comparing their estimates with the actual strengths 260 previously determined experimentally.

\section{$261 \quad 3.1 \quad$ Strength versus w/b relationships for concretes with FA}

Preliminary studies were needed to determine concrete mix proportions that would result

264 in nominal cube compressive strengths of 50 and $75 \mathrm{MPa}$ at 28-days, i.e. corresponding 265 to concretes of Grade C32/40 and C55/67 respectively. The best way to achieve this was 266 to first determine the strength versus w/b ratio relationships for Portland cement mixes 267 and for mixes with partial cement replacements with FA of 15, 30 and 45\%. These are 268 shown in Figure 2, as are strength curves used in the BRE mix design method (Teychenne 269 et al. 1997). FA mixes clearly require a lower w/b ratio to achieve the same strength as 270 PC mixes. For Grade C32/40 the w/b needs to be reduced from 0.54 to 0.37 and for the 271 Grade C55/67 the w/b needs to be reduced from 0.46 to 0.30 when $45 \%$ of the Portland 272 cement is replaced with FA. Reduction of the w/b requires an increase in the binder in 273 order to maintain the consistency of the concrete. The binder content was increased from 274389 to $489 \mathrm{~kg} / \mathrm{m}^{3}$ for the Grade C32/40. The binder content for the Grade C55/67 was 275 only slightly increased from 317 to $369 \mathrm{~kg} / \mathrm{m}^{3}$ and this was because the superplasticizer 276 dosage was increased at the same time from $0.2 \%$ to $0.35 \%$ solids by weight of binder. 


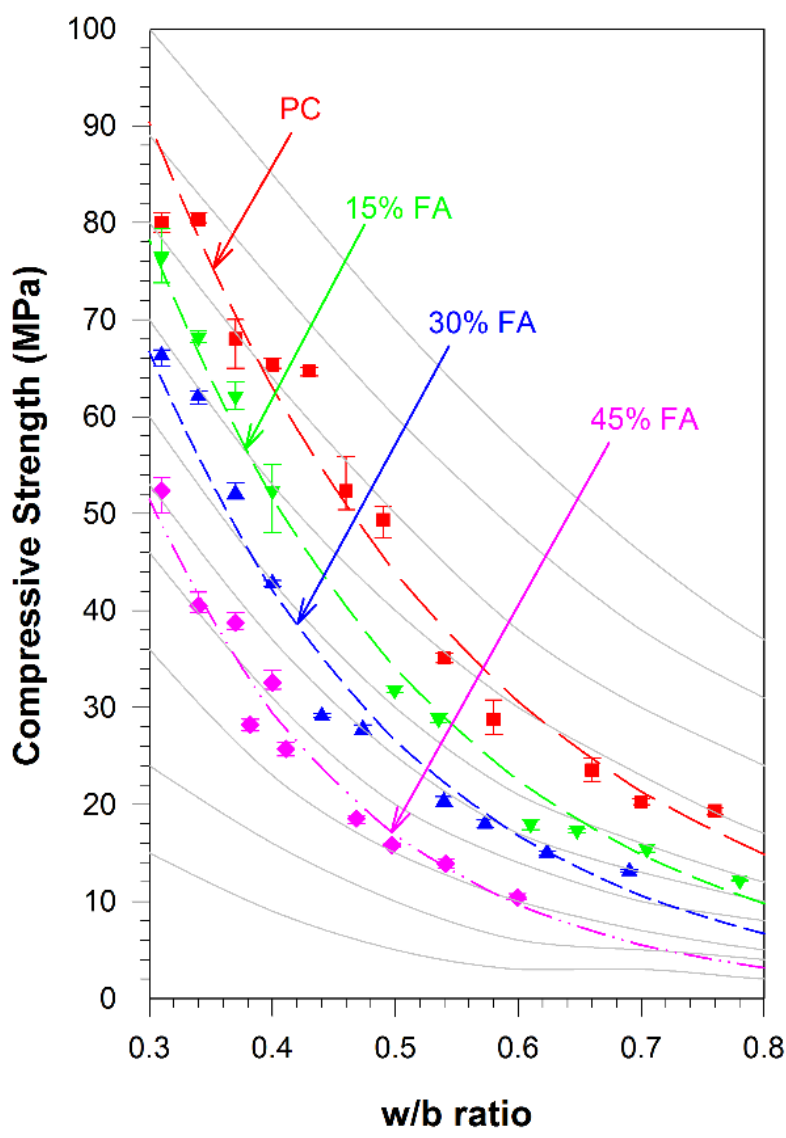

277

278

279

280

281 PC and FA concrete strengths versus time (days) relationships, see Figure 3, are 282 surprisingly very similar up to 28-days, i.e. the early age strength does not seem to have 283 been affected significantly with the use of FA. This may be because FA mixes required 284 lower w/b ratios to achieve the same 32-day strength as PC mixes. The strength 285 development of PC concrete is clearly slowing down after 28-days whilst that of FA 286 mixes is continuing. At 256 days the FA concretes have significantly higher cube 287 compressive strengths, up to $10 \mathrm{MPa}$ for the C32/40 and $20 \mathrm{MPa}$ for the $\mathrm{C} 55 / 67$. 


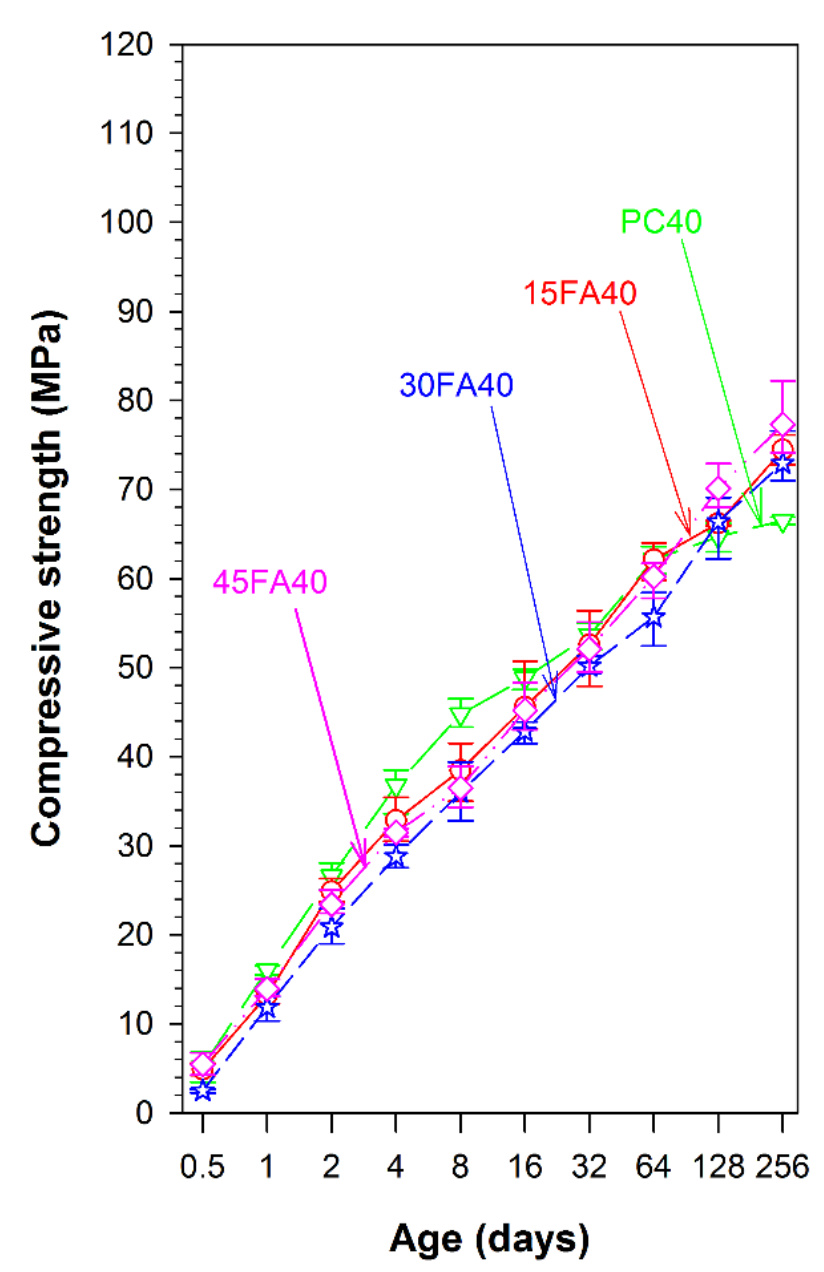

a) Grade $C 32 / 40$

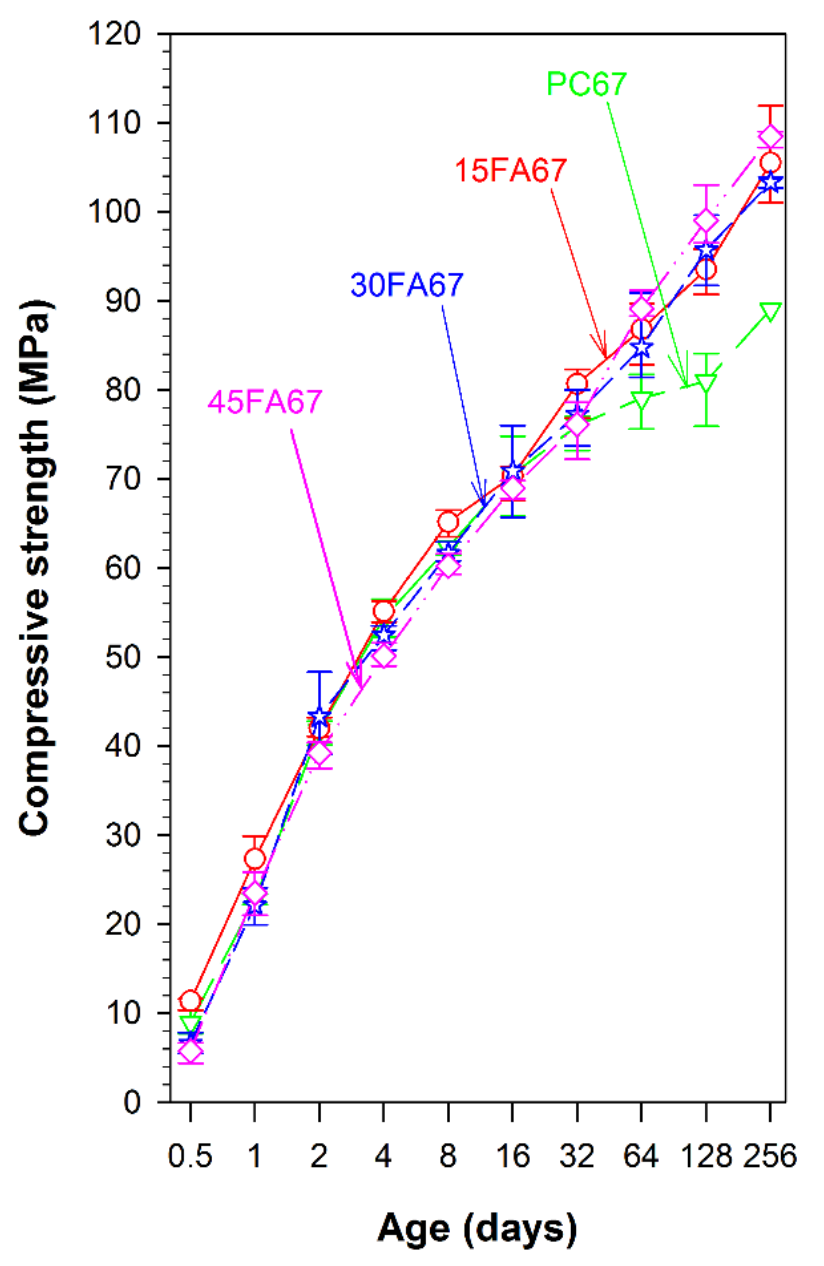

b) Grade $\mathrm{C} 55 / 67$

292 Figure 3: Strength development of fly ash (FA) mixes at standard $\left(20^{\circ} \mathrm{C}\right)$ curing 293 temperature. 


\section{$295 \quad 3.2 \quad$ Effect of temperature on concrete strength development}

296

297 The compressive strength development with age at different curing temperatures is

298 shown in Figures 4 and 5 for concrete Grades C32/40 and C55/67, respectively. Equation

2994 was used to obtain regression lines through the strength data and the regression

300 constants for all the mixes are shown in Tables 3 and 4. 
Table 3: $\quad$ Regression constants for strength-time relationship for C32/40 (Equation 4).

302

\begin{tabular}{|c|c|c|c|c|c|c|c|c|c|c|c|c|c|c|c|c|c|}
\hline \multirow{3}{*}{\multicolumn{2}{|c|}{\begin{tabular}{|c|} 
Concrete Grade \\
Mix ID \\
Regression constants
\end{tabular}}} & \multicolumn{16}{|c|}{ C32/40 } \\
\hline & & \multicolumn{4}{|c|}{ PC40 } & \multicolumn{4}{|c|}{$15 F A 40$} & \multicolumn{4}{|c|}{$30 F A 40$} & \multicolumn{4}{|c|}{$45 F A 40$} \\
\hline & & $\mathbf{S}_{\mathbf{u}}$ & $\mathbf{k}$ & $\mathbf{t}_{0}$ & $\mathbf{R}^{2}$ & $\mathbf{S}_{\mathbf{u}}$ & $\mathbf{k}$ & $\mathbf{t}_{\mathbf{0}}$ & $\mathbf{R}^{2}$ & $\mathbf{S}_{\mathbf{u}}$ & $\mathbf{k}$ & $\mathbf{t}_{\mathbf{0}}$ & $\mathbf{R}^{2}$ & $\mathbf{S}_{\mathbf{u}}$ & $\mathbf{k}$ & $\mathbf{t}_{\mathbf{0}}$ & $\mathbf{R}^{2}$ \\
\hline \multirow{5}{*}{ च } & 10 & 68.3 & 0.16 & 0.34 & 0.994 & 64.2 & 0.15 & 0.34 & 0.989 & 61.8 & 0.14 & 0.36 & 0.985 & 65.7 & 0.12 & 0.15 & 0.987 \\
\hline & 20 & 63.8 & 0.32 & 0.14 & 0.985 & 68.2 & 0.18 & $1.5 \mathrm{E}-09$ & 0.968 & 67.2 & 0.14 & $1.2 \mathrm{E}-09$ & 0.967 & 70.7 & 0.15 & $3.5 \mathrm{E}-09$ & 0.960 \\
\hline & 30 & 62.2 & 0.64 & 0.16 & 0.996 & 65.5 & 0.29 & $9.1 \mathrm{E}-10$ & 0.975 & 72.9 & 0.19 & $9,4 \mathrm{E}-10$ & 0.978 & 83.1 & 0,16 & $1.9 \mathrm{E}-09$ & 0.975 \\
\hline & 40 & 59.1 & 0.90 & 0.08 & 0.994 & 64.0 & 0.42 & 1.4E-09 & 0.980 & 73.6 & 0.33 & $1.6 \mathrm{E}-09$ & 0.985 & 79.4 & 0.29 & $1.2 \mathrm{E}-09$ & 0.989 \\
\hline & 50 & 54.2 & 1.23 & 0.01 & 0.994 & 59.3 & 0.61 & $2.4 \mathrm{E}-10$ & 0.985 & 68.9 & 0.53 & $4.7 \mathrm{E}-10$ & 0.998 & 71.7 & 0.67 & 0.01 & 0.995 \\
\hline
\end{tabular}

$* S_{u}, k$ and $t_{0}$ in $M P a$, days ${ }^{-1}$ and days, respectively

Table 4: $\quad$ Regression constants for strength-time relationship for C55/67 (Equation 4).

\begin{tabular}{|c|c|c|c|c|c|c|c|c|c|c|c|c|c|c|c|c|c|}
\hline \multirow{3}{*}{\multicolumn{2}{|c|}{$\begin{array}{c}\begin{array}{c}\text { Concrete } \\
\text { Grade }\end{array} \\
\text { Mix ID } \\
\begin{array}{l}\text { Regression } \\
\text { constants* }\end{array}\end{array}$}} & \multicolumn{16}{|c|}{$C 55 / 67$} \\
\hline & & \multicolumn{4}{|c|}{ PC67 } & \multicolumn{4}{|c|}{$15 F A 67$} & \multicolumn{4}{|c|}{ 30FA67 } & \multicolumn{4}{|c|}{$45 F A 67$} \\
\hline & & $\mathbf{S}_{\mathbf{u}}$ & $\mathbf{k}$ & $\mathbf{t}_{\mathbf{0}}$ & $\mathbf{R}^{2}$ & $\mathbf{S}_{\mathbf{u}}$ & $\mathbf{k}$ & $\mathbf{t}_{\mathbf{0}}$ & $\mathbf{R}^{2}$ & $\mathbf{S}_{\mathbf{u}}$ & $\mathbf{k}$ & $\mathbf{t}_{0}$ & $\mathbf{R}^{2}$ & $\mathbf{S}_{\mathbf{u}}$ & $\mathbf{k}$ & $\mathbf{t}_{\mathbf{0}}$ & $\mathbf{R}^{2}$ \\
\hline \multirow{5}{*}{ 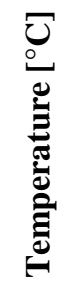 } & 10 & 83.9 & 0.25 & 0.37 & 0.984 & 93.3 & 0.20 & 0.31 & 0.985 & 90.6 & 0.20 & 0.28 & 0.981 & 93.1 & 0.13 & 0.23 & 0.981 \\
\hline & 20 & 82.9 & 0.48 & 0.22 & 0.991 & 94.2 & 0.33 & 0.04 & 0.969 & 93.3 & 0.31 & 0.14 & 0.967 & 98.5 & 0.22 & $1.3 \mathrm{E}-01$ & 0.961 \\
\hline & 30 & 76.7 & 0.81 & 0.15 & 0.997 & 91.0 & 0.49 & $9.6 \mathrm{E}-10$ & 0.975 & 92.1 & 0.35 & $1.2 \mathrm{E}-09$ & 0.967 & 98.3 & 0.29 & $1.8 \mathrm{E}-09$ & 0.962 \\
\hline & 40 & 71.9 & 1.22 & 0.12 & 0.997 & 88.2 & 0.67 & $1.2 \mathrm{E}-09$ & 0.980 & 95.2 & 0.46 & $1.1 \mathrm{E}-09$ & 0.979 & 102.2 & 0.42 & $1.3 \mathrm{E}-09$ & 0.979 \\
\hline & 50 & 64.9 & 1.85 & 0.06 & 0.990 & 81.0 & 1.0 & $1.5 \mathrm{E}-10$ & 0.980 & 85.8 & 0.83 & $6.5 \mathrm{E}-10$ & 0.994 & 94.8 & 0.78 & 0.07 & 0.993 \\
\hline
\end{tabular}

$* S_{u}, k$ and $t_{0}$ in $M P a$, days ${ }^{-1}$ and days, respectively 
308 As expected, the strength development of all the concretes depended on the curing 309 temperature. At early ages, the strength was higher at higher temperatures since the rate 310 of reaction was greater. The "cross-over" effect, i.e. high curing temperature results in a 311 greater strength than a low curing temperature at early ages, and conversely results in 312 lower strength at later ages (McIntosh, 1956), is apparent for the PC40 and PC67

313 concretes. It is less apparent as the percentage of fly ash in the concrete mixes increases. 314 The $50{ }^{\circ} \mathrm{C}$ strength development curve crosses the $20{ }^{\circ} \mathrm{C}$ at a much later age with 315 increasing fly ash and therefore at a much higher compressive strength. In some cases, 316 especially for the concrete Grade C32/40, the $50{ }^{\circ} \mathrm{C}$ strength development curve only 317 crosses those of the 40 and $30^{\circ} \mathrm{C}$ but not the $20^{\circ} \mathrm{C}$ at the high percentages of fly ash. 

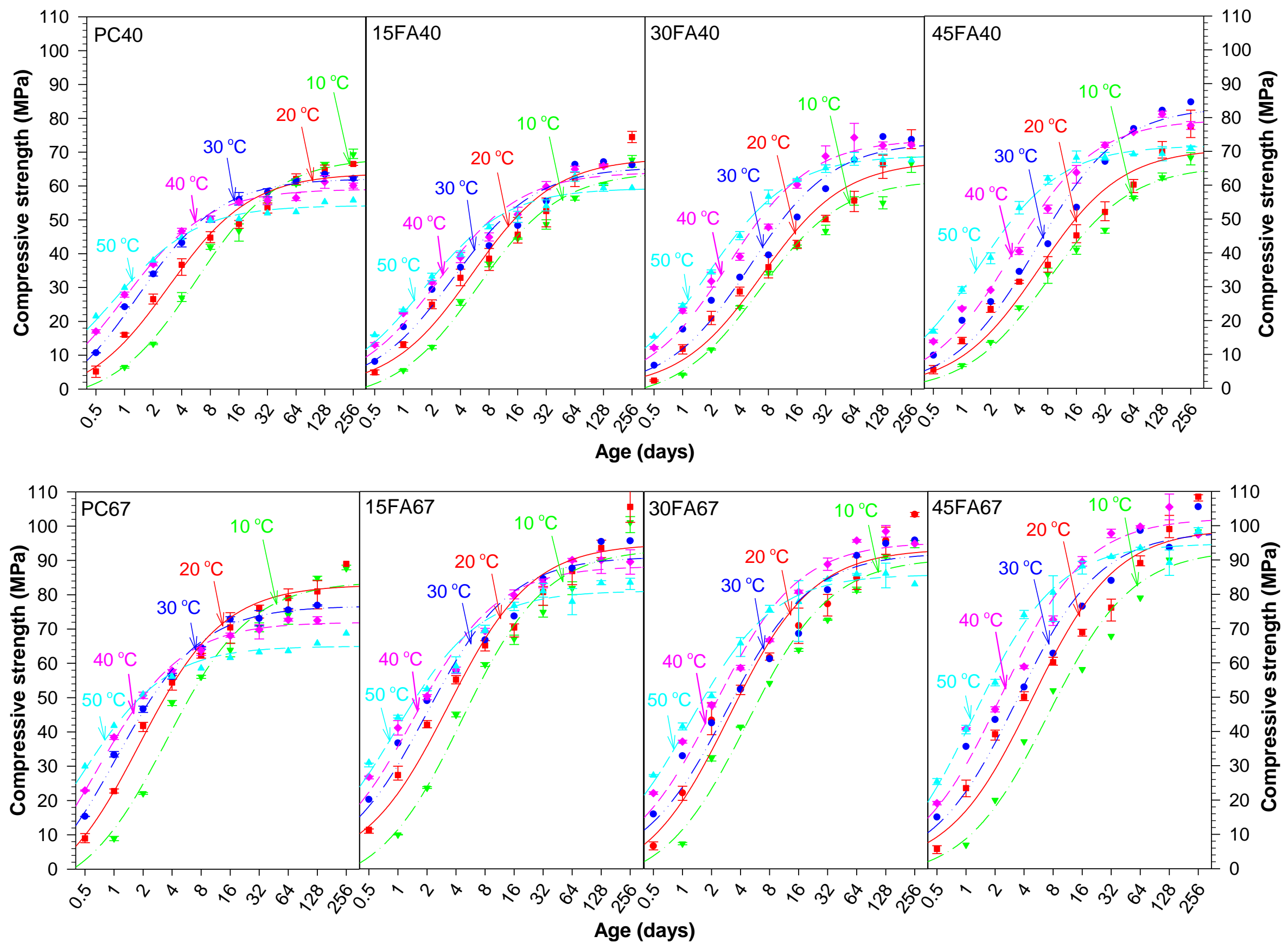

Figure 4: $\quad$ Strength development for concrete Grade C32/40 and C55/67. 
The relative strengths, i.e. the strength ratios of the strengths at 30,40 and $50{ }^{\circ} \mathrm{C}$ to those at $20{ }^{\circ} \mathrm{C}$ curing, are shown in Figures 5 for concrete Grades C32/40 and C55/67. This figure clearly shows the benefit of higher curing temperatures on the early age strength development of all the concretes. The beneficial effect at early ages seems to be similar irrespective of the percentage of fly ash in the concrete. 1-day strength ratios of $50{ }^{\circ} \mathrm{C}$ with $20{ }^{\circ} \mathrm{C}$ curing strengths for PC concretes were 1.9 and 1.8 for Grades C32/40 and C55/67, respectively. Those of similar concretes with $45 \%$ fly ash were 2.1 and 1.7 for Grades C32/40 and C55/67, respectively. The beneficial effect is not as high as for 50\% ground granulated blast furnace slag mixes previously reported to be as high as 4.6 at 1day for a $50 \mathrm{MPa}$ equivalent mortar (Soutsos et al. 2017). 


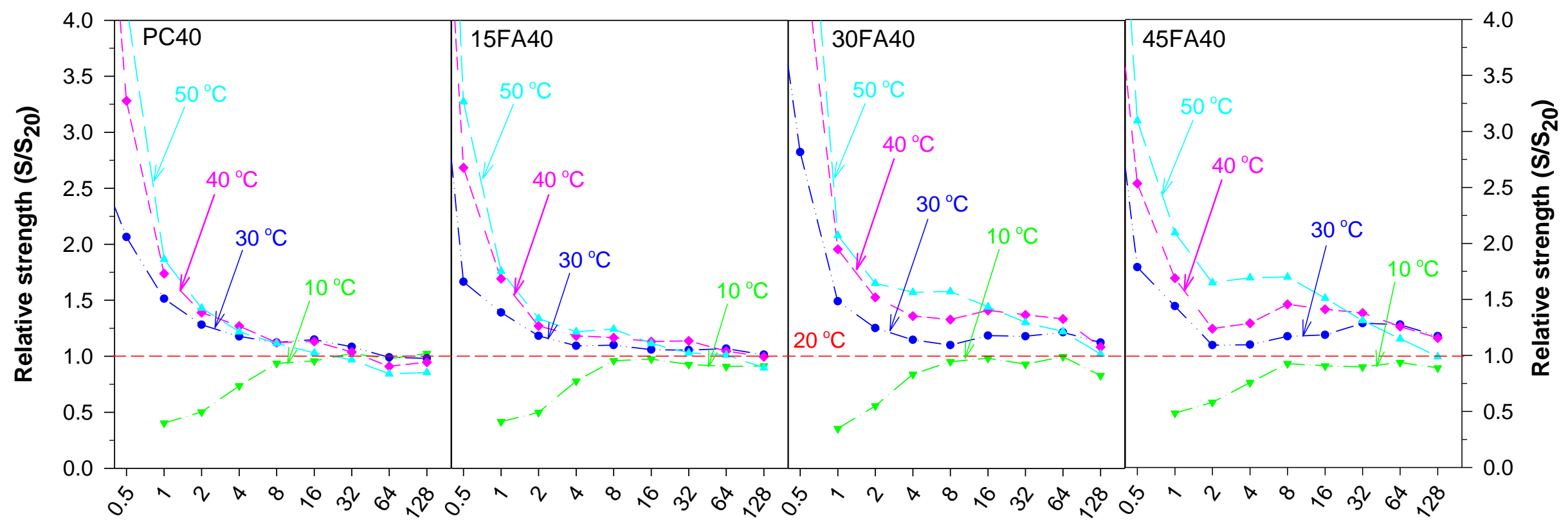

Age (Days)

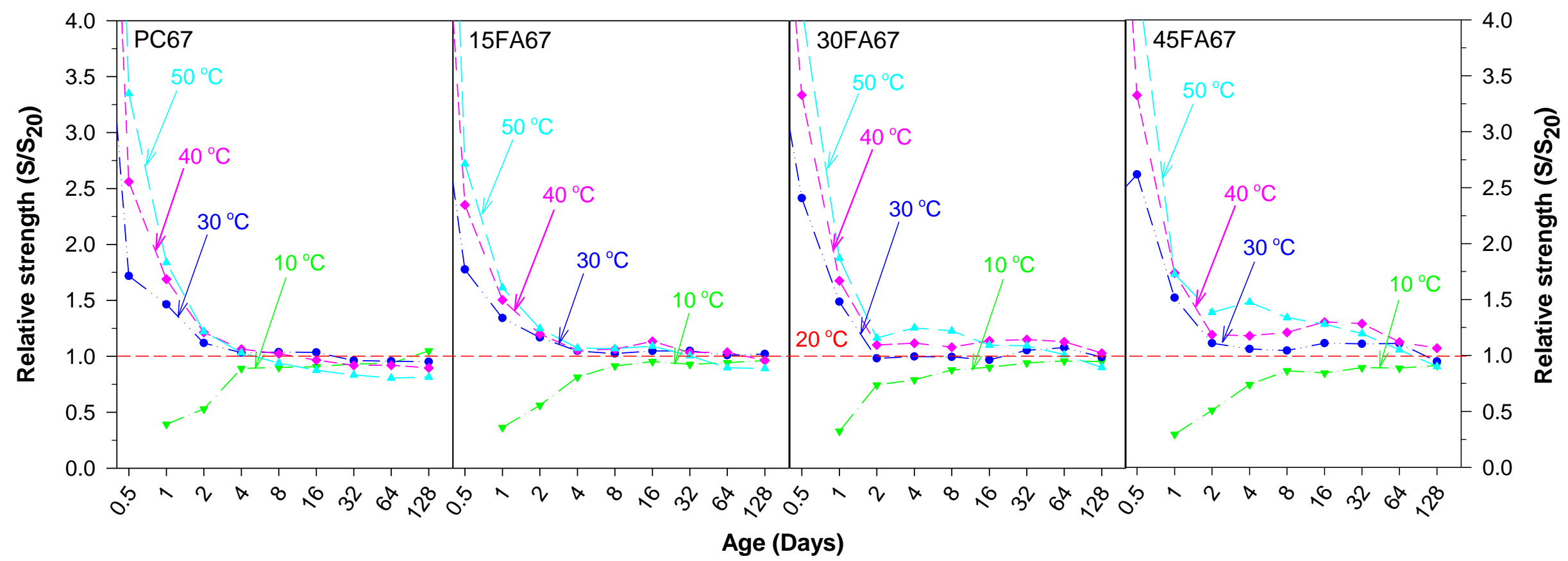

Figure 5: $\quad$ Relative strengths (ratio of actual strength $(\mathrm{S})$ to $20{ }^{\circ} \mathrm{C}$ curing strength $\left(\mathrm{S}_{20}\right)$ ) of concrete Grade $\mathrm{C} 32 / 40$ and $\mathrm{C} 55 / 67$. 


\subsection{Determination of "apparent" activation energies}

In order to calculate the "apparent" activation energy, $E_{a}$, the ASTM C1074-11 recommendation (ASTM, 2011) is to plot $\ln (k)$, obtained from Equation 4 and shown in Tables 3 and 4 , against $1 / T_{a b s}$ (given in $1 /$ Kelvin), where $T_{a b s}$ is the absolute curing temperature. The negative of the slope of the line, i..e. $-Q$, is the "apparent" activation energy, $E_{a}$, divided by the universal gas constant, $R$ (equal to $8.31 \mathrm{~J} / \mathrm{K} \cdot \mathrm{mol}$ gas), i.e. $-Q$ $=E_{a} / R$ or $E_{a}=-Q \cdot R$. The plots of $\ln (k)$ versus $1 / T_{a b s}$ are shown in Figure 6(a) and (b) for the concrete Grades C32/40 and C55/67, respectively. The "apparent" activation energies, $E_{a}$, obtained are shown in Figure 7. Fly ash (FA) mixes appear to have slightly lower "apparent" activation energies than PC mixes.

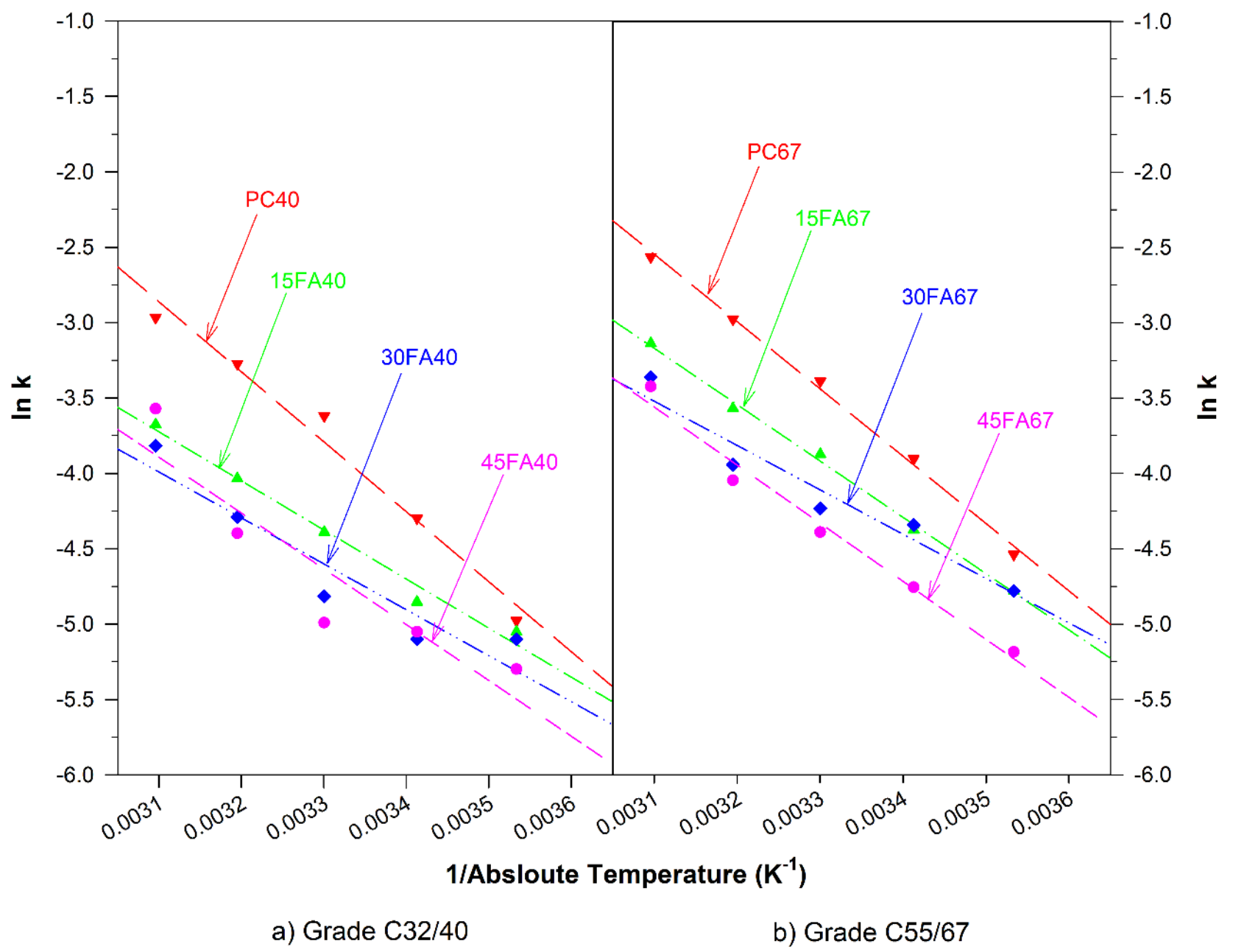

Figure 6: Determination of "apparent" activation energies - $\ln (k)$ against $1 / T_{\text {abs. }}$ 


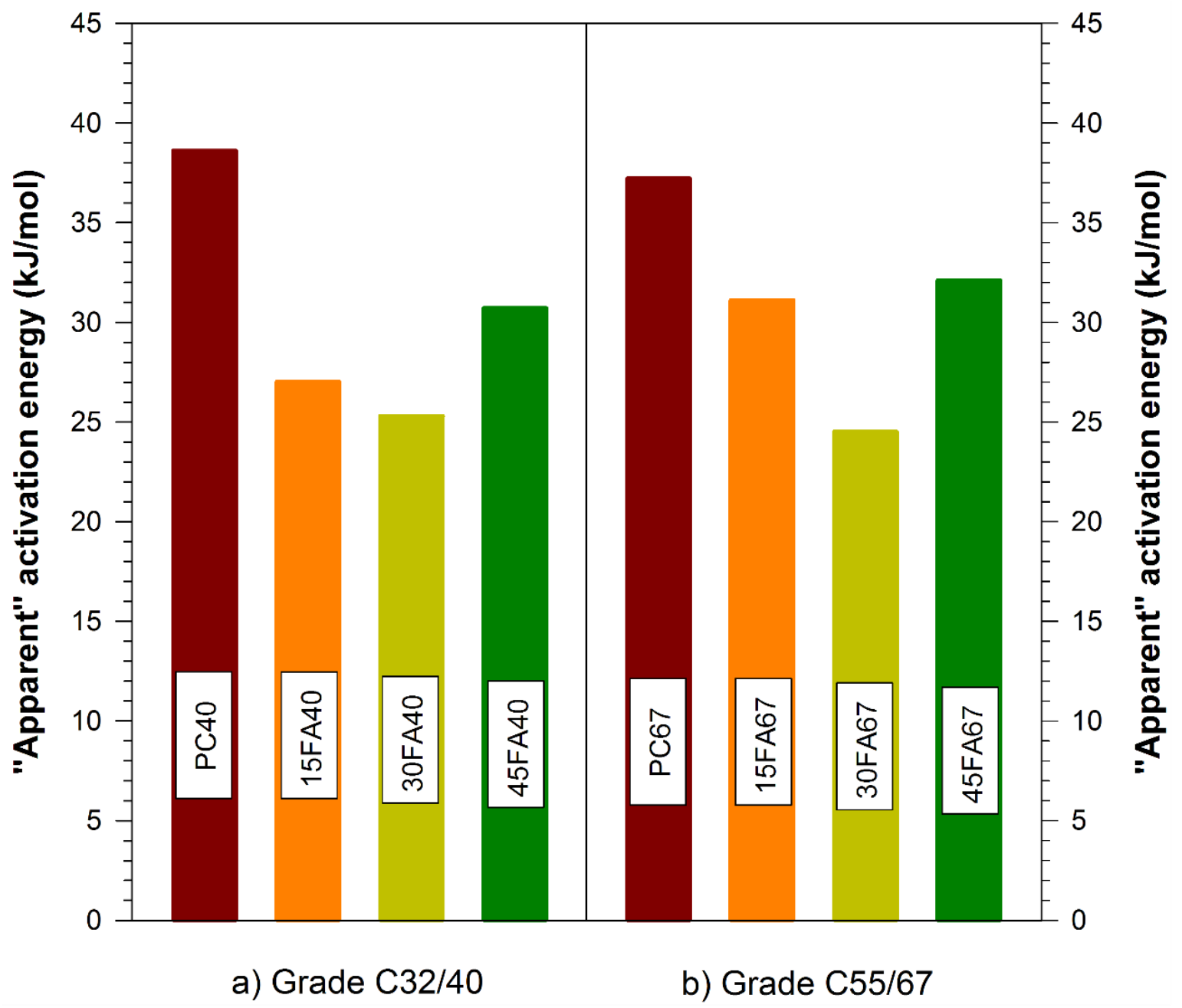

Figure 7: "Apparent" activation energies for concrete Grades C32/40 and C55/67.

The "age conversion factor" converts a curing interval $\Delta t$ to the equivalent curing interval at the reference temperature (Carino, 2004). The age conversion factor of the Nurse-Saul function can be obtained from Equation 4 by rewriting it as follows (Carino, 2004):

$$
t_{e}=\sum \alpha \cdot \Delta t
$$

Equation 5

The age conversion factor, $\alpha$, is therefore:

$$
\alpha=\frac{T-T_{0}}{T_{r}-T_{0}}
$$


where: $\quad t_{e} \quad$ is the equivalent age at the reference temperature (days),

$\mathrm{T}_{\mathrm{r}} \quad$ is the reference temperature $\left({ }^{\circ} \mathrm{C}\right)$,

$\mathrm{T}$ is the average temperature $\left(20^{\circ} \mathrm{C}\right.$ for standard curing) over the time interval $\Delta \mathrm{t}\left({ }^{\circ} \mathrm{C}\right)$,

$\mathrm{T}_{0} \quad$ is the datum temperature $\left({ }^{\circ} \mathrm{C}\right)$,

$\alpha \quad$ is the age conversion factor.

In the case of the Arrhenius function, the age conversion factor is:

$$
\alpha=e^{-\frac{E_{a}}{R} \cdot\left(\frac{1}{T_{r}}-\frac{1}{T}\right)} .
$$

Equation 8

The age conversion factors for different curing temperatures were calculated from Equation 6 and the estimated activation energies for the investigated mixes were used with Equation 8. The reference temperature was taken to be $20^{\circ} \mathrm{C}$. The age conversion factors increase exponentially with temperature. The linear relationship for the variation of the age conversion factor with temperature assumed by the Nurse-Saul model is inadequate to describe the temperature sensitivity of all the concretes. The deviation from linear relationship of the age conversion factor with temperature is greater for Portland cement (PC) than for fly ash (FA) concretes. This again indicates that the activation energies of fly ash (FA) concretes, and thus the effect of temperature on their strength gain rates, are lower than those of Portland cement (PC) concretes of equivalent compressive strength. 


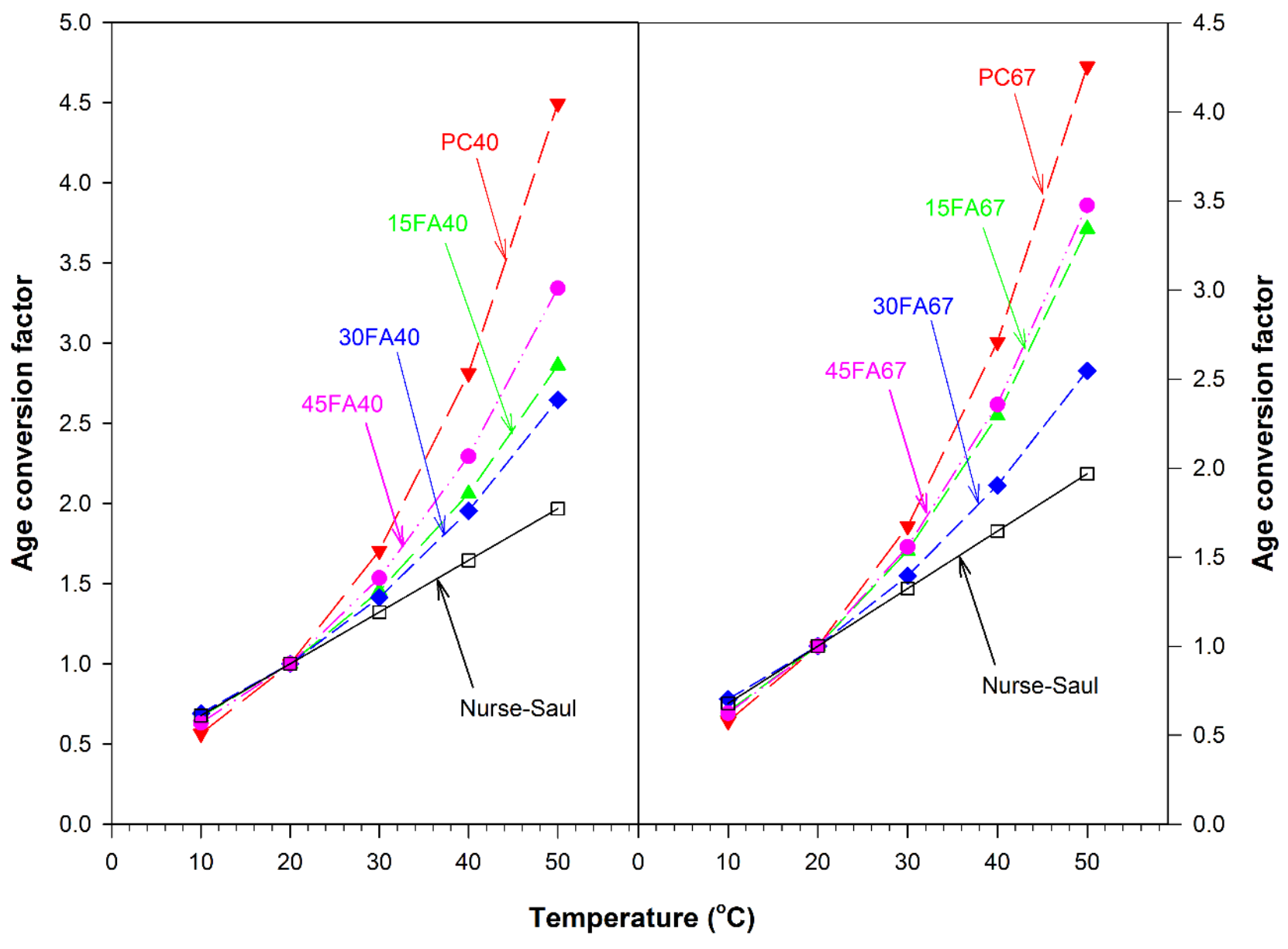

a) Grade $C 32 / 40$

b) Grade $C 55 / 67$

Figure 8: $\quad$ Effect of curing temperature on age conversion factor.

Table 5 shows "apparent" activation energy values found in the literature and these have been plotted in Figure 9. "Apparent" activation energy values for neat Portland cement (CEM I or Type I) seem to be in the range from 30 to $50 \mathrm{~kJ} / \mathrm{mol}$, although there are some exceptionally high values as high as $64 \mathrm{~kJ} / \mathrm{mol}$. There is only a limited number of values for "apparent" activation energies for FA mixes in the literature. The ones obtained from this work appear to indicate that partial cement replacement with FA will decrease the "apparent" activation energy. 


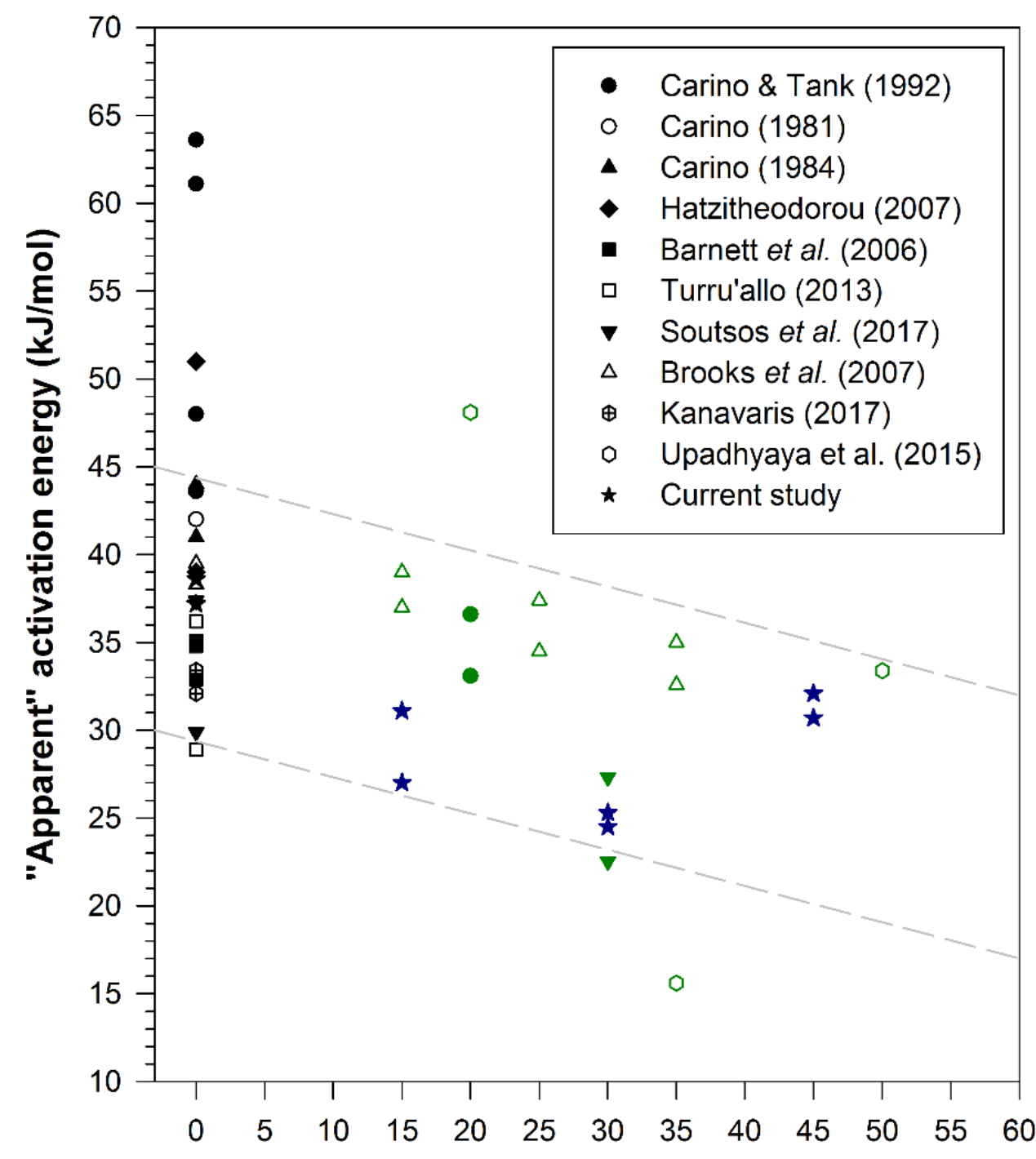

Fly ash replacement level (\%)

Figure 9: "Apparent" activation energies obtained from literature and current study. 
Table 5: "Apparent" activation energies from literature based on compressive tests on concretes and mortars.

\begin{tabular}{|c|c|c|c|c|c|}
\hline $\begin{array}{c}\text { Cement } \\
\text { type }\end{array}$ & FA level & $\mathbf{w} / \mathbf{b}$ & $\begin{array}{c}\text { "Apparent" activation } \\
\text { energy [kJ/mol] }\end{array}$ & Source & Year \\
\hline CEM I & \multirow{18}{*}{$\begin{array}{c}\text { Neat Portland cement } \\
{[100 \% \text { PC }]}\end{array}$} & 0.54 & $38.6^{+}$ & Current study & 2018 \\
\hline CEM I & & 0.46 & $37.2^{+}$ & Current study & 2018 \\
\hline CEM I & & 0.66 & $37.4^{\#}$ & Soutsos et al. (2017) & 2017 \\
\hline Type I & & 0.60 & $48.0^{+}$and $43.6^{\#}$ & Carino \& Tank (1992) & 1992 \\
\hline CEM I & & 0.46 & $29.7^{\#}$ & Soutsos et al. (2017) & 2017 \\
\hline CEM I & & 0.45 & $39.3^{\#}$ & Hatzitheodorou (2007) & 2007 \\
\hline Type I & & - & $42.0^{\#}$ & Carino (1981) & 1981 \\
\hline Type I & & - & $41.0^{+}$and $44.0^{\#}$ & Carino (1984) & 1984 \\
\hline CEM I & & 0.60 & $34.8^{\#}$ & Barnett et al. (2006) & 2006 \\
\hline CEM I & & 0.40 & $35.1^{\#}$ & Barnett et al. (2006) & 2006 \\
\hline CEM I & & 0.26 & $32.9^{\#}$ & Barnett et al. (2006) & 2006 \\
\hline Type I & & 0.37 & $39.0^{\#}$ & Brooks et al. (2007) & 2007 \\
\hline Type I & & 0.50 & $38.3^{\#}$ & Brooks et al. (2007) & 2007 \\
\hline Type I & & 0.50 & $39.5^{\#}$ & Brooks et al. (2007) & 2007 \\
\hline CEM I & & 0.51 & $36.2^{\#}$ & Turru'allo (2013) & 2013 \\
\hline CEM I & & 0.33 & $28.9^{\#}$ & Turru'allo (2013) & 2013 \\
\hline CEM I & & 0.51 & 33.42 and 32.06 & Kanavaris (2017) & 2017 \\
\hline Type I & & 0.45 & $61.1^{\#}$ and $63.6^{+}$ & Carino \& Tank (1992) & 1992 \\
\hline Type I & \multirow{4}{*}{$15 \% \mathrm{FA}$} & 0.37 & $37.0^{\#}$ & Brooks et al. (2007) & 2007 \\
\hline Type I & & 0.38 & $39.0^{\#}$ & Brooks et al. (2007) & 2007 \\
\hline CEM I & & 0.50 & $27.0^{+}$ & Current study & 2018 \\
\hline CEM I & & 0.41 & 31.1 ${ }^{+}$ & Current study & 2018 \\
\hline Type I & \multirow{3}{*}{$20 \% \mathrm{FA}$} & 0.45 & $33.1^{\#}$ and $30.0^{+}$ & Carino \& Tank (1992) & 1992 \\
\hline Type I & & 0.60 & $36.6^{\#}$ and $31.2^{+}$ & Carino \& Tank (1992) & 1992 \\
\hline Type I & & 0.50 & $48.1^{\#}$ & Upadhyaya et al. (2015) & 2015 \\
\hline Type I & \multirow{2}{*}{$25 \% \mathrm{FA}$} & 0.38 & $35.5^{\#}$ & Brooks et al. (2007) & 2007 \\
\hline Type I & & 0.39 & $37.7^{\#}$ & Brooks et al. (2007) & 2007 \\
\hline CEM I & \multirow{4}{*}{$30 \% \mathrm{FA}$} & 0.35 & $27.3^{\#}$ & Soutsos et al. (2017) & 2017 \\
\hline CEM I & & 0.53 & $22.5^{\#}$ & Soutsos et al. (2017) & 2017 \\
\hline CEM I & & 0.44 & $25.3^{+}$ & Current study & 2018 \\
\hline CEM I & & 0.35 & $24.5^{+}$ & Current study & 2018 \\
\hline Type I & \multirow{3}{*}{$35 \% \mathrm{FA}$} & 0.38 & $35.0^{\#}$ & Brooks et al. (2007) & 2007 \\
\hline Type I & & 0.40 & $32.6^{\#}$ & Brooks et al. (2007) & 2007 \\
\hline Type I & & 0.50 & $15.6^{\#}$ & Upadhyaya et al. (2015) & 2015 \\
\hline CEM I & \multirow{2}{*}{$45 \% \mathrm{FA}$} & 0.37 & $30.7^{+}$ & Current study & 2018 \\
\hline CEM I & & $\mathbf{0 . 3 0}$ & 32.1 ${ }^{+}$ & Current study & 2018 \\
\hline Type I & $50 \% \mathrm{FA}$ & 0.39 & $33.4^{\#}$ & Upadhyaya et al. (2015) & 2015 \\
\hline
\end{tabular}

+ - concrete, ${ }^{\#}$ - mortar 


\subsection{Applicability/accuracy of maturity functions for the strength development}

Maturity functions use the experimentally determined strength-age relationship at a reference temperature (usually at $20^{\circ} \mathrm{C}$ ) to estimate the strength at any other temperature.

The Nurse-Saul function requires the temperature history, in this case the curing temperature, of the concrete in order to calculate the maturity index according to Equation 1. The equivalent age $t_{e}$ at time $t$ was calculated using Equation 2. The value of equivalent age obtained, $t_{e}$, was then substituted for $t$ in Equation 1 with constants $S_{u}, k$ and $t_{0}$, as previously determined for the strength data obtained for the concrete cured at $20^{\circ} \mathrm{C}$ (see Tables 3 and 4 ) and the estimated strength was thus obtained.

The Arrhenius function required the "apparent" activation energies which are shown in Figure 7. The equivalent age $t_{e}$ at time $t$ was calculated using Equation 3. The specified reference temperature, $T_{s}$, used was $293{ }^{\circ} \mathrm{K}\left(20^{\circ} \mathrm{C}\right) . T_{a}$ being the average temperature, in Kelvin, of concrete during time interval $\Delta t$ was none other than the curing temperature. The value of equivalent age obtained, $t_{e}$, was then substituted for $t$ in Equation 4 with constants $S_{u}, k$ and $t_{0}$, as previously determined for the strength data obtained for the concrete cured at $20^{\circ} \mathrm{C}$ (see Tables 3 and 4). The estimated strength was thus obtained.

The Nurse-Saul function generally under-estimated the early age strengths for all the concretes up to four days, see Figure 10. The 32-day strength estimates for both strength grades of Portland cement concretes was over-estimated and this is due to the inability of this function to account for the detrimental effect high early age temperatures have on later age strength. The estimates for the strength of fly ash (FA) concretes continue to be relatively accurate for longer ages as the "cross-over" effect (firstly reported by McIntosh (McIntosh, 1956)) is not as pronounced as for Portland cement (PC) mortars and it does occur much later.

The Arrhenius function over-estimated the strength of the Portland cement mixes even at an early age, see Figures 11 . This may be due to the cross-over effect that appears to affect Portland cement (PC) mixes very early-on. It is contrary to the Nurse-Saul function 
which under-estimated the early age strengths. This is because the Arrhenius function considers that the strength gain rate varies exponentially with temperature, as shown in Figure 8. If the strength estimates of the Arrhenius function are correct, then the detrimental effect of high curing temperature starts from early age and it is maintained for long term strengths. The strength estimates are more accurate for FA concretes since the cross-over effect occurs at much later ages. 

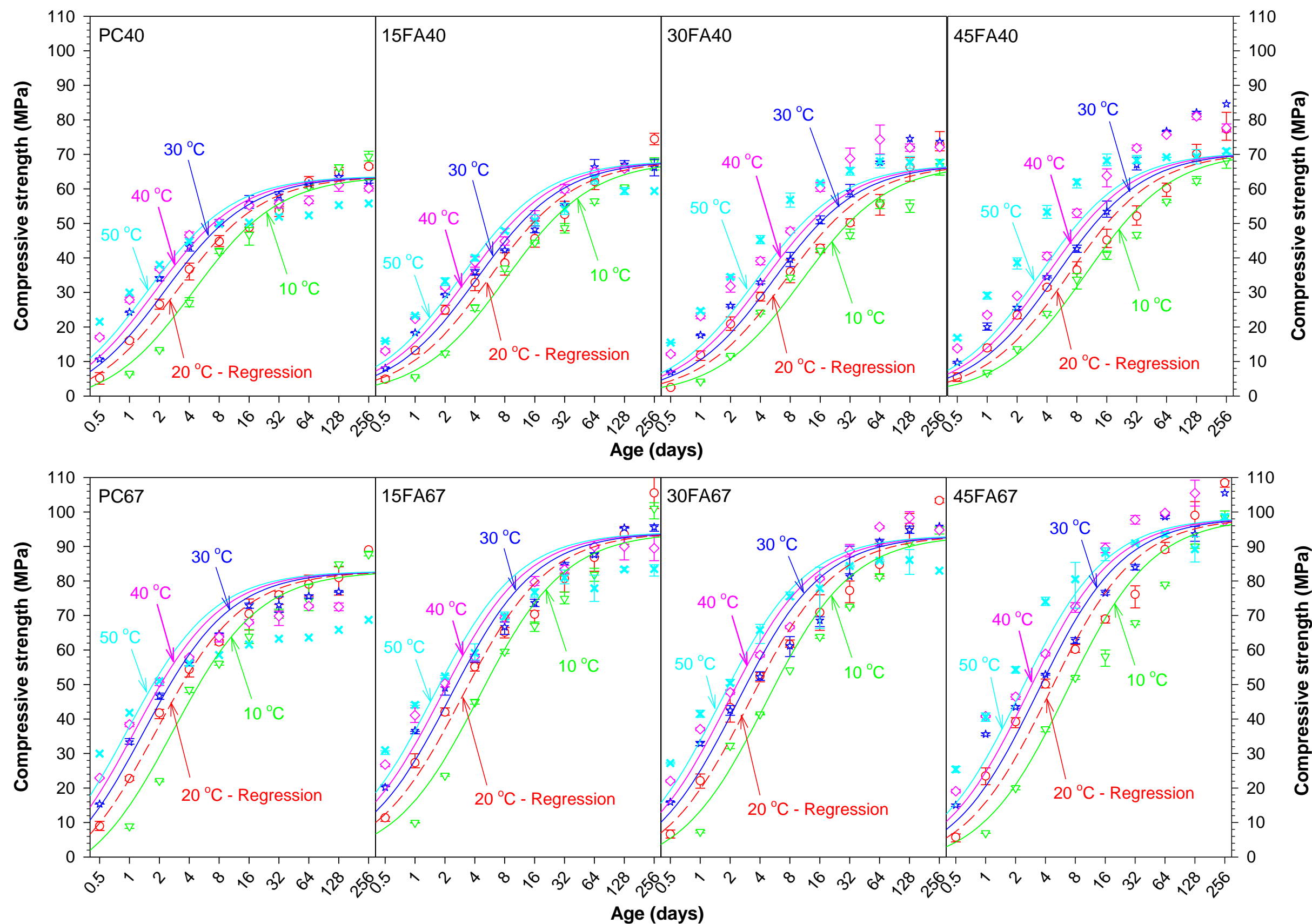

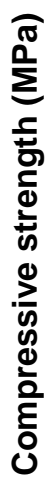

Figure 10: Nurse-Saul compressive strength estimates for Grade C32/40 and C55/67 concretes. 

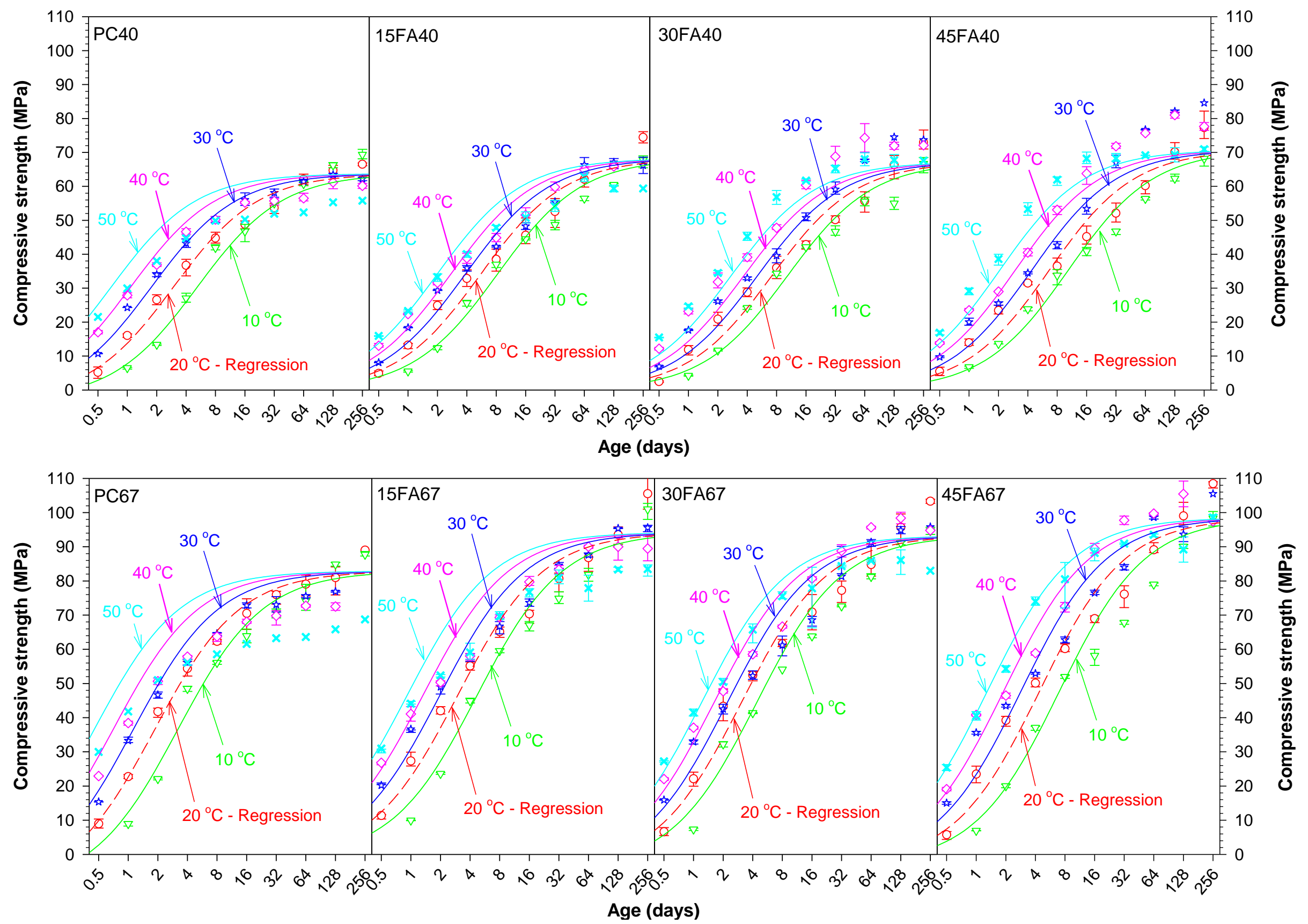

Figure 11: Arrhenius compressive strength estimates for Grade C32/40 and C55/67 concretes. 
The ratios of estimates to actual strength are shown in Figures 12 and 13. These confirm that the Nurse-Saul function underestimates the effect of high early age curing temperatures on the early age strength. The estimated/actual strength ratios are below one for up to four days for the Grade C32/40 concretes and up to two days for the Grade C55/67 concretes. Strengths of Portland cement concretes are overestimated at later ages because the Nurse-Saul function does not account for the long-term detrimental effect of high early age curing temperatures. The strength estimates for the fly ash (FA) concretes tend to be accurate for later ages, even up to 128 days, as the "cross-over" effect is not as pronounced, and it occurs much later than for Portland cement (PC) concretes.

The Arrhenius function on the other hand, overestimates even early age strength, especially at the higher curing temperatures, for Portland cement (PC) concretes. This may be due to the detrimental effect starting from very early age at particularly the high curing temperatures. The Arrhenius function's strength estimates for the fly ash (FA) concretes tend to be accurate for later ages for the same reasons as for the Nurse-Saul function discussed above. 
罗,

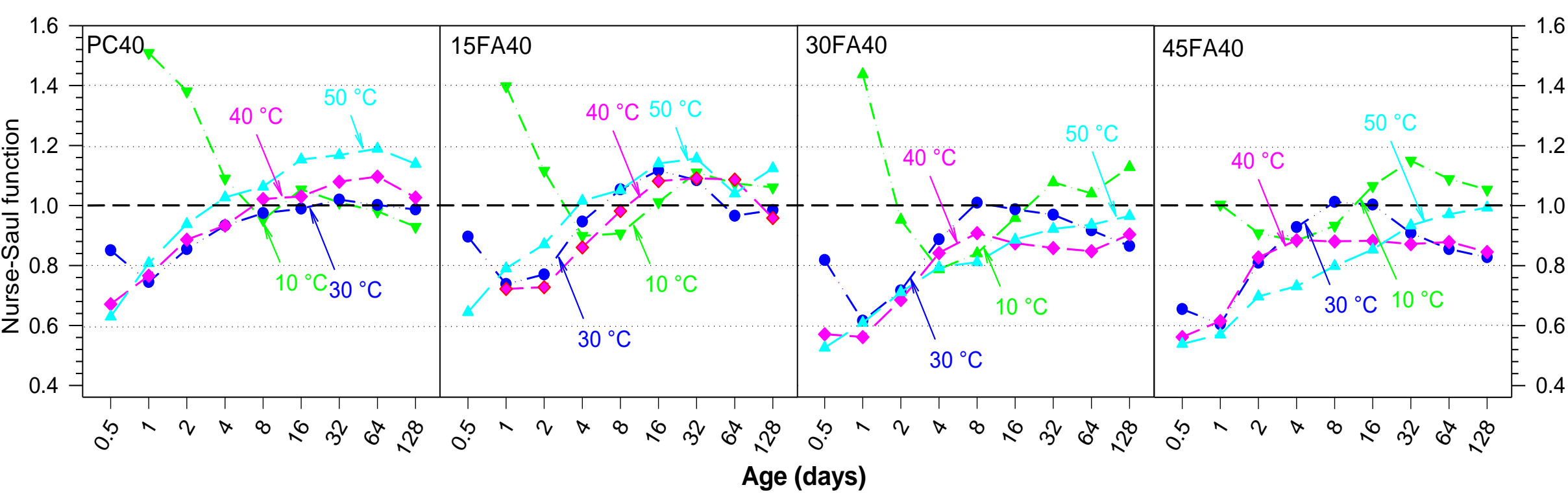

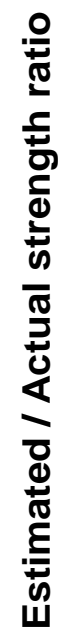

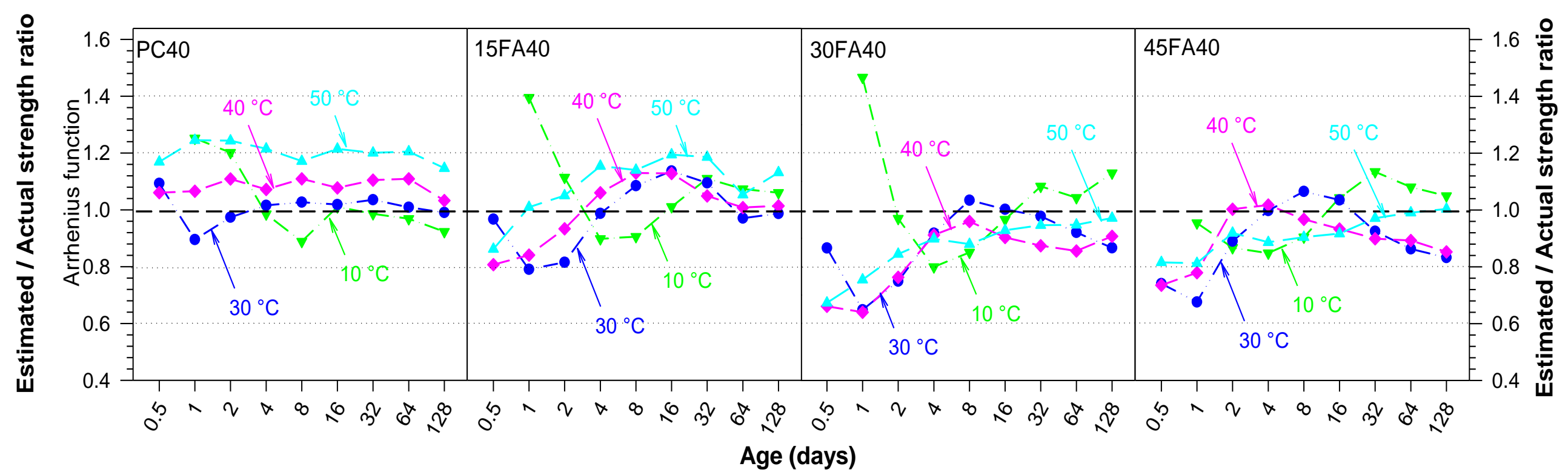

Figure 12: $\quad$ Estimated and actual strength ratios for Grade C32/40 concretes based on the Nurse-Saul and Arrhenius function. 


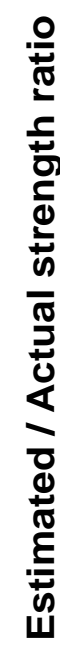

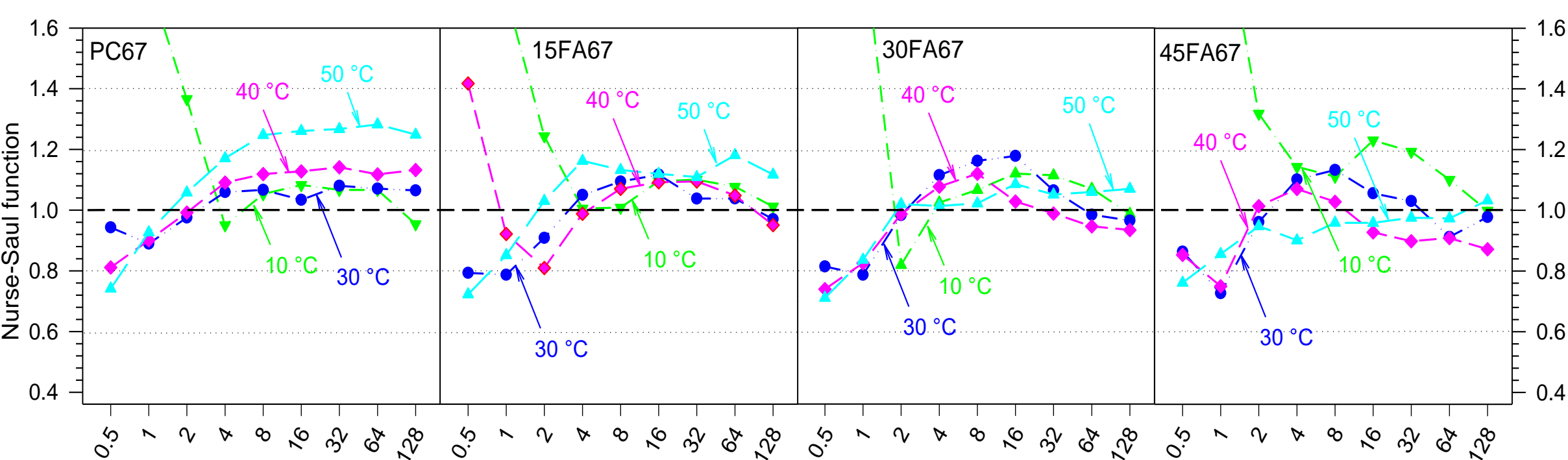

Age (days)

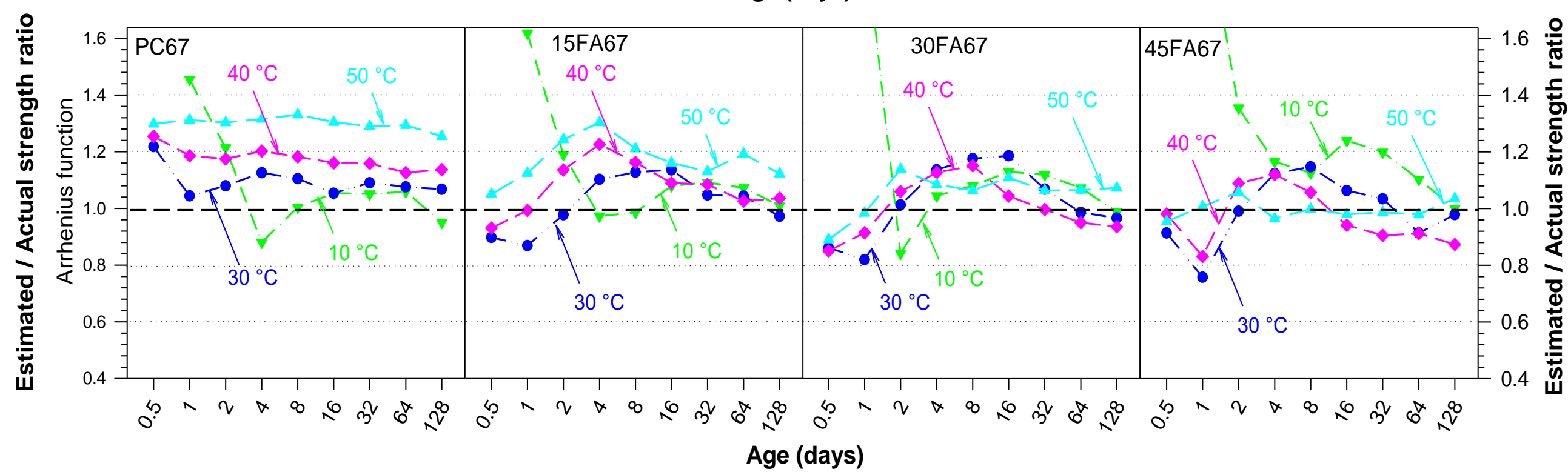

Figure 13: $\quad$ Estimated and actual strength ratios for Grade C55/67 concretes based on the Nurse-Saul and Arrhenius function. 


\section{Conclusions}

The effect of temperature on the strength development of mixes with fly ash (FA) has been investigated. The conclusions are:

- High curing temperatures have a beneficial effect on the early age strength but a detrimental effect on the long-term strength development. This resulted in the "cross-over" effect which was more pronounced for Portland cement (PC) concretes as it occurred much earlier than for fly ash (FA) concretes.

- Fly ash (FA) concrete mixes have been shown to be less sensitive to curing at high temperatures than Portland cement (PC) concretes and this was reflected in their lower "apparent" activation energies.

- The Nurse-Saul function underestimated the effect of high early age curing temperatures on the early age strength for Portland cement (PC) and fly ash (FA) concretes.

- The Arrhenius function overestimated the early age strengths of Portland cement (PC) concretes. This appears to be because of the detrimental effect starting from a very early age. It overestimated long-term strengths as it did not account for the detrimental effect of high curing temperatures on the ultimate compressive strength. The strength estimates are more accurate for fly ash (FA) concretes since the cross-over effect occurs at much later ages than Portland cement (PC) concretes.

Work is continuing aiming to determine modifications to the maturity functions in order to improve estimates of both early age and long term strength development with and without fly ash (FA) (Soutsos and Kanavaris, 2018b, 2020). 


\section{Acknowledgements}

The majority of the experimental work described here was carried out by Dr Mohammed Elsageer at the University of Liverpool as part of his $\mathrm{PhD}$ research. The authors are grateful to the School of Engineering, the University of Liverpool for the facilities provided and to the Engineering and Physical Sciences Research Council, UK (GR/R83880/01), for the financial support received for the equipment. The contents of this paper reflect the views of the authors, who are responsible for the validity and accuracy of presented data, and do not necessarily reflect the views of their affiliated organisations.

\section{References}

ASTM (2011) ASTM C1074-11 Standard practice for estimating concrete strength by the maturity method, West Conshohocken, Pennsylvania, USA, ASTM International.

Babu KG and Rao GSN (1994) Early strength behaviour of fly ash concretes, Cement and Concrete Research 24(2), pp. 277-284.

Barnett SJ, Soutsos MN, Millard SG et al. (2006) Strength development of mortars containing ground granulated blast-furnace slag: Effect of curing temperature and determination of apparent activation energies, Cement and Concrete Research 36(3) pp. 434-440.

Boubekeur T, Ezziane K and Kadri E (2014) Estimation of mortars compressive strength at different curing temperature by the maturity method, Construction and Building Materials 71, pp. 299-307. 
BSI (1992) BS 882:1992 - Specification for aggregates from natural sources for concrete, London, UK.

BSI (2011) BS EN 197-1:2011 - Cement. Composition, specifications and conformity criteria for common cements, London, UK.

BSI (2002) BS EN 12620:2002+A1:2008 - Aggregates for concrete, London, UK.

BSI (2005) BS EN 196-1-2005 - Methods of testing cement. Determination of strength, London, UK.

BSI (2012) BS EN 450-1:2012 - Fly ash for concrete. Definition, specifications and conformity criteria, London, UK.

Carino NJ (1981) Temperature Effects on the Strength-Maturity Relation of Mortar, Report No. NBSIR 81-2244.

Carino NJ (1984) The maturity method: Theory and application, Journal of Cement, Concrete and Aggregates (ASTM) 6(2), pp. 61-73.

Carino NJ and Tank RC (1992) Maturity Functions for Concretes Made with Various Cements and Admixtures, ACI Material Journal 89(2), pp. 188-196.

Carino NJ (2004) The Maturity Method, In: Handbook on Nondestructive Testing of Concrete (Malhotra VM and Carino NJ (eds)), 2nd ed. CRC Press, pp. 5.1-5.47.

Domone, P.L.J. and Soutsos, M.N., “An Approach To The Proportioning Of High Strength Concrete Mixes", Concrete International, Vol. 6, No. 10, October 1994, pp. 26-31.

Freiseleben Hansen P and Pedersen EJ (1977) Maturity computer for controlled curing and hardening of concrete, Nord. Betong, 1, p. 19.

Galobardes I, Cavalaro S, Goodier CI et al. (2015) Maturity method to predict the evolution of 
the properties of sprayed concrete, Construction and Building Materials 79, pp. 357-369.

Hatzitheodorou A (2007) Insitu Strength Development of Concretes with Supplementary Cementitious Materials, PhD thesis, University of Liverpool, UK.

Kanavaris F Early age behaviour and cracking risk of concretes containing GGBS, PhD Thesis, Queen's University Belfast, Belfast, UK, 2017.

McIntosh JD (1956) The effects of low-temperature curing on the compressive strength of concrete, In Proceedings of RILEM symposium on winter concreting, Session BII, Copenhagen: Danish Institute for Building Research.

Nurse RW (1949) Steam curing of concrete, Magazine of Concrete Research 1(2), pp. 79-88.

Parsons TJ and Naik TR (1985) Early age strength determination by maturity, Concrete International 7(2), pp. 37-43.

Poole JL, Riding KA, Juenger MSCG, Folliard KJ and Schindler A (2011) Effect of Chemical Admixtures on Apparent Activation Energy of Cementitious Systems, Journal of Materials in Civil Engineering, Volume 23 Issue 12.

Vollpracht, A. Soutsos MN and Kanavaris F (2018) Strength development of GGBS and fly ash concretes and applicability of fib model code's maturity function - A critical review, Construction and Building Materials 162, pp. 830-846.

Saul AGA, (1951) Principles underlying the steam curing of concrete at atmospheric pressure, Magazine of Concrete Research 2(6), pp. 127-140.

Soutsos MN, Turu'allo G, Owens K et al. (2013) Maturity Testing of Lightweight SelfCompacting and Vibrated Concretes, Construction and Building Materials 47, pp. 118125. 
Soutsos MN, Hatzitheodorou A, Kwasny J and Kanavaris F (2016) Effect of in situ temperature on the early age strength development of concretes with supplementary cementitious materials, Construction and Building Materials 103, pp. 105-116.

Soutsos MN, Hatzitheodorou A, Kanavaris F and Kwasny J (2017) Effect of temperature on the strength development of mortar mixes with GGBS and fly ash, Magazine of Concrete Research 69(15), pp. 787-801.

Soutsos M, Kanavaris F and Hatzitheodorou (2018a) Critical analysis of strength estimates from maturity functions, Case Studies in Construction Materials, 8.

Soutsos M and Kanavaris F (2018b) The Modified Nurse-Saul (MNS) maturity function for improved strength estimates at elevated curing temperatures, Case Studies in Construction Materials, 8.

Soutsos MN, Hatzitheodorou A, Kanavaris F and Kwasny J (2019) Compressive Strength Estimates of Adiabatically Cured Concretes Using Maturity Methods, Journal of Materials in Civil Engineering 31(7).

Soutsos M and Kanavaris F (2020) Compressive strength estimates for adiabatically cured concretes with the Modified Nurse-Saul (MNS) maturity function, Construction and Building Materials, 255.

Tank RC and Carino NJ (1991) Rate constant functions for strength development of concrete, ACI Material Journal 88(1), pp. 74-83.

Teychenne DC, Franklin RE and Erntroy HC (1997) Design of normal concrete mixes, BRE Press, 2nd edition.

Turu'allo G (2013) Early age strength development of GGBS concrete cured under different 
temperatures, PhD Thesis, The University of Liverpool, Liverpool, UK.

Upadhyaya, S., Goulias, D. and Obla, K. (2015) "Maturity-based field strength predictions of sustainable concrete using high-volume fly ash as supplementary cementitious material", J. Mat. Civ. Eng. 27(5), p. 7.

Wirquin E, Broda M and Bruno. D (2002) Determination of the Apparent Activation Energy of one Concrete by Calorimetric and Mechanical Means - Influence of a Superplasticizer, Cement and Concrete Research 32(8):1207-1213.

Yikici TA and Chen H (2015) Use of maturity method to estimate compressive strength of mass concrete, Construction and Building Materials 95, pp. 802-812. 